Cover photo: Mangrove forest at Enipoas, Pohnpei. Photograph by Kevin Buffington, April 12, 2019. 


\section{Mangrove Species' Response to Sea-Level Rise Across Pohnpei, Federated States of Micronesia}

By Kevin J. Buffington, Rich A. MacKenzie, Joel A. Carr, Maybeleen Apwong,

Ken W. Krauss, and Karen M. Thorne

Prepared in cooperation with the U.S. Forest Service

Open-File Report 2021-1002 


\section{U.S. Geological Survey, Reston, Virginia: 2021}

For more information on the USGS - the Federal source for science about the Earth, its natural and living resources, natural hazards, and the environment—visit https://www.usgs.gov or call 1-888-ASK-USGS.

For an overview of USGS information products, including maps, imagery, and publications, visit https://store.usgs.gov/.

Any use of trade, firm, or product names is for descriptive purposes only and does not imply endorsement by the U.S. Government.

Although this information product, for the most part, is in the public domain, it also may contain copyrighted materials as noted in the text. Permission to reproduce copyrighted items must be secured from the copyright owner.

Suggested citation:

Buffington, K.J., MacKenzie, R.A., Carr, J.A., Apwong, M., Krauss, K.W., and Thorne, K.M., 2021, Mangrove species' response to sea-level rise across Pohnpei, Federated States of Micronesia: U.S. Geological Survey Open-File Report 2021-1002, 44 p., https://doi.org/10.3133/ofr20211002.

Associated data for this publication:

Irwin, J.R., Gesch, D.B., Buffington, K.J., and Danielson, J.J., 2021, Pohnpei, Federated States of Micronesia Mangrove Elevation Survey Data: U.S. Geological Survey data release, https://doi.org/10.5066/P9DDZX32.

ISSN 2331-1258 (online) 


\section{Acknowledgments}

This work was funded by Department of Interior Office of Insular Affairs, U.S. Geological Survey (USGS) Land Carbon program, and the USGS Pacific Island Climate Adaptation Science Center. The project was conceptualized by C. Swensen at the U.S. Fish and Wildlife Service and Zhu Zhiliang at the USGS. For help with field work, logistics, or general information, we would like to thank Tamara Greenstone Alefaio (Micronesia Conservation Trust), Francisca Sohl, Angel Jonathan, Bejay Obispo, Kirino Olpet (Conservation Society of Pohnpei), Eugene Eperiam, Emos Eperiam, Bersin Elias, and Yosda Sailas (Pohnpei Department of Forestry). Additional contextual and field data were provided by Joanna Ellison (University of Tasmania).

We also would like to thank our USGS colleagues Dean Gesch, Jeff Irwin, and Jeff Danielson (Earth Resources Oobservation and Science) for lending their expertise to collecting elevation data, and Zhu Zhiliang (Climate Adapation Science Center) and Elitsa Peneva-Reed (Eastern Geographic Science Center) for their invaluable forest inventory dataset. Support was provided by USGS Western Ecological Research Center and University of California, Davis, Center for Aquatic Biology and Aquaculture. 



\section{Contents}

Acknowledgments ……...................................................................................................................

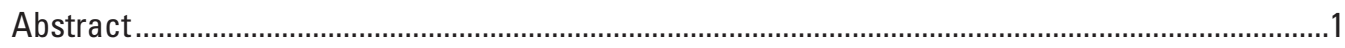

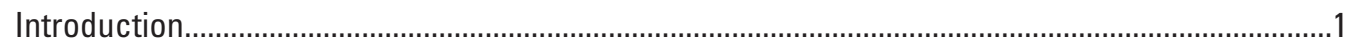

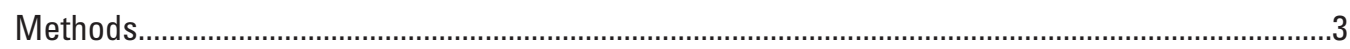

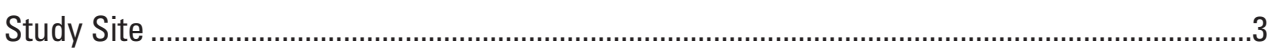

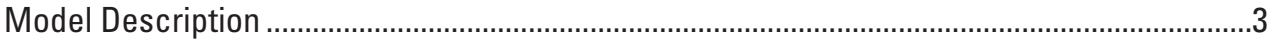

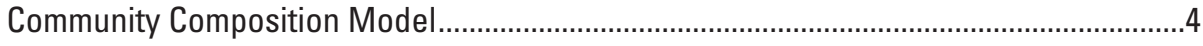

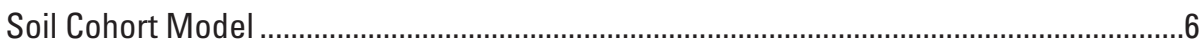

Surface Deposition ..........................................................................................................

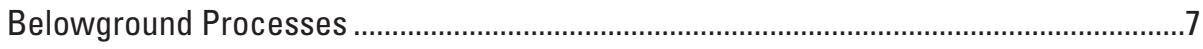

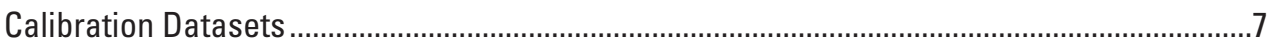

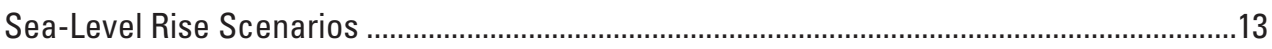

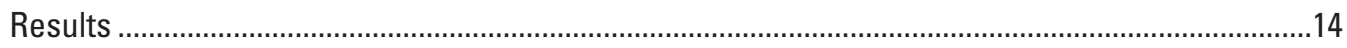

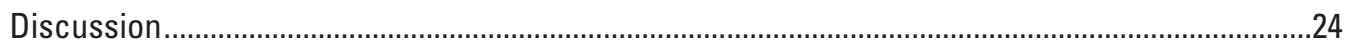

Modeling Assumptions and Information Needs ..............................................................2

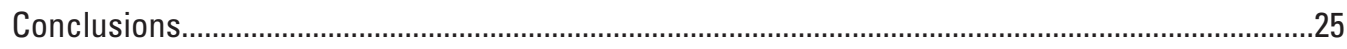

References Cited.............................................................................................................25

Appendix 1. Model equations for Mangrove Species' Response to Sea-Level Rise,

Pohnpei, Federated States of Micronesia ......................................................................28

Appendix 2. Model Calibration of Mangrove Species' Response to Sea-Level Rise, Pohnpei, Federated States of Micronesia

\section{Figures}

1. Photographs showing dominant mangrove species of Pohnpei, Federated States of Micronesia

2. Diagram showing approach to simulating surface-elevation relative to sea-level rise around Pohnpei, Micronesia, by modeling above and belowground organic and mineral pools and processes in mangrove forests...

3. Diagram showing model approach for how fractional mangrove basal area is apportioned to above and belowground living and dead biomass pools...

4. Maps showing location and digital elevation model of study sites around Pohnpei, Federated States of Micronesia, relative to large watersheds...

5. Graph showing relationship between organic matter percentage and bulk density from mangrove soil cores across Pohnpei, Federated States of Micronesia......9

6. Graph showing elevation probability distribution functions for five common mangrove species on Pohnpei, Federated States of Micronesia

7. Graph showing elevation profile with distance from the seaward edge, derived from elevation leveling datasets at northern and southern study sites Pohnpei, Federated State of Micronesia...

8. Graphs showing sea-level rise scenarios simulated for 2020-2100 used to assess mangrove vulnerability on Pohnpei, Federated States of Micronesia.

9. Chart showing mean observed and modeled accretion rates during the 20-year validation period for two sites with data from surface elevation tables, Pohnpei, Federated States of Micronesia. 
10. Graphs showing mean elevation for the seven study sites on Pohnpei,

Federated States of Micronesia, under three sea-level rise scenarios from 2020 to 2100

11. Graphs showing average mangrove area for each region on Pohnpei,

Federated States of Micronesia, under sea-level rise scenarios from 2020 to 2100 ......17

12. Graphs showing percentage of the Enipein, Palikir, Pwudoi, and West study areas on Pohnpei, Federated States of Micronesia, covered by each mangrove species projected to have more than15-percent cover under low, moderate, high, and extreme sea-level rise scenarios from 2020 to 2100

13. Graphs showing percentage of the Alohkapw, Enipoas, and Sapwalap study areas on Pohnpei, Federated States of Micronesia, covered by each mangrove species projected to have more than 15-percent cover under low, moderate, high, and extreme sea-level rise scenarios from 2020 to 2100

14. Images showing mangrove community composition across Pohnpei, Federated States of Micronesia, under 2020 conditions and $37 \mathrm{~cm}$ of sea-level rise by 2100 in 20-year intervals

15. Images showing mangrove community composition across Pohnpei, Federated States of Micronesia, under 2020 conditions and $52 \mathrm{~cm}$ of sea-level rise by 2100 in 20-year intervals

16. Images showing Mangrove community composition across Pohnpei, Federated States of Micronesia, under 2020 conditions and $67 \mathrm{~cm}$ of sea-level rise by 2100 in 20-year intervals

17. Images showing Mangrove community composition across Pohnpei, Federated States of Micronesia, under 2020 conditions and $117 \mathrm{~cm}$ of sea-level rise by 2100 in 20-year intervals.

\section{Tables}

1. Mangrove species growth-rate parameters in the model from Devoe and Cole (1998)

2. Fractional basal area to aboveground biomass linear regression coefficients and shoot:root ratios for each mangrove species

3. Allometric equations estimating aboveground volume from tree diameter for most common mangrove species on Pohnpei, from Cole and others (1999)

4. Mean soil-core accretion rates, organic and mineral accumulation rates, elevation, along with the regional mean sea-level estimate at study sites on Pohnpei, Federated States of Micronesia

5. Site elevation values for mangrove vulnerability to sea-level rise model for Pohnpei, Federated States of Micronesia, and root mean squared error

6. Model parameters for the seven mangrove study sites, Pohnpei, Federated States of Micronesia. 


\section{Conversion Factors}

International System of Units to U.S. customary units

\begin{tabular}{lcl}
\hline \multicolumn{1}{c}{ Multiply } & By & \multicolumn{1}{c}{ To obtain } \\
\hline & Length & \\
\hline millimeter $(\mathrm{mm})$ & 0.03937 & inch (in.) \\
centimeter $(\mathrm{cm})$ & 0.3937 & inch (in.) \\
meter $(\mathrm{m})$ & 3.281 & feet (ft) \\
meter $(\mathrm{m})$ & 1.094 & yard (yd) \\
kilometer $(\mathrm{km})$ & 0.6214 & mile (mi) \\
kilometer $(\mathrm{km})$ & 0.5400 & mile, nautical $(\mathrm{nmi})$ \\
\hline & Area & \\
\hline square meter $\left(\mathrm{m}^{2}\right)$ & 4,047 & acre \\
square kilometer $\left(\mathrm{km}^{2}\right)$ & 247.1 & acre \\
\hline & Volume & \\
\hline cubic meter $\left(\mathrm{m}^{3}\right)$ & 1.308 & cubic yard $\left(\mathrm{yd}^{3}\right)$ \\
\hline
\end{tabular}

\section{Datum}

Vertical coordinate information is referenced to the Earth Gravitational Model 2008 (EGM2008)

Horizontal coordinate information is referenced to the World Geodetic System of 1984 (WGS 84)

\section{Abbreviations}

$\begin{array}{ll}\text { DEM } & \text { digital elevation model } \\ \text { ENSO } & \text { El Niño-Southern Oscillation } \\ \text { FSM } & \text { Federated States of Micronesia } \\ \text { GAM } & \text { general additive model } \\ \text { MHW } & \text { mean high water } \\ \text { MLW } & \text { mean low water } \\ \text { MSL } & \text { mean sea level } \\ \text { RCP } & \text { representative concentration pathway } \\ \text { RMSE } & \text { root mean squared error } \\ \text { SET } & \text { surface elevation table }\end{array}$





\title{
Mangrove Species' Response to Sea-Level Rise Across Pohnpei, Federated States of Micronesia
}

\author{
By Kevin J. Buffington, ${ }^{1}$ Rich A. MacKenzie, ${ }^{2}$ Joel A. Carr, ${ }^{3}$ Maybeleen Apwong, ${ }^{2}$ Ken W. Krauss, ${ }^{4}$ and \\ Karen M. Thorne1
}

\section{Abstract}

Mangrove forests are likely vulnerable to accelerating sea-level rise; however, we lack the tools necessary to understand their future resilience. On the Pacific island of Pohnpei, Federated States of Micronesia, mangroves are habitat to endangered species and provide critical ecosystem services that support local communities. We developed a generalizable modeling framework for mangroves that accounts for species interactions and the belowground processes that dictate soil elevation. The modeling framework was calibrated with extensive field datasets, including accretion rates derived from thirty 1-meter-deep soil cores dated with lead-210, more than 300 forest inventory plots, water-level monitoring, and differential leveling elevation surveys. We applied the model using a community of five mangrove species and across seven regions around Pohnpei to identify which regions are most vulnerable to sea-level rise. The responses of mean elevation and the mangrove community composition were analyzed under four global sea-level rise scenarios: an increase of 37, 52, 67 , or 117 centimeters by 2100 . The model was validated against a 20-year surface elevation table record (1999-2019) and showed good agreement when driven by observed water levels.

The model projected that mangroves around Pohnpei can build their elevations relative to moderate rates of sea-level rise to prevent submergence, with limited changes in mangrove community composition through 2060. By 2100 , however, the model projected a decreasing abundance of high-elevation mangrove species and an increasing abundance of lower elevation species adapted to more persistent flooding. Under higher sea-level rise scenarios, forest elevation decreased substantially relative to mean sea level and there were more drastic changes in the tree community composition

\footnotetext{
${ }^{1}$ U.S. Geological Survey, Western Ecological Research Center

${ }^{2}$ U.S. Forest Service, Institute of Pacific Islands Forestry

${ }_{3}^{3}$ U.S. Geological Survey, Patuxent Wildlife Research Center

${ }^{4}$ U.S. Geological Survey, Wetland and Aquatic Research Center
}

and loss of suitable mangrove habitat by 2100 . Variation in accretion rates, water levels, and initial forest elevation led to differential vulnerability around the island, such that mangroves on the leeward side of the island generally were the most at-risk to higher rates of sea-level rise. Our findings indicate that the relatively undisturbed state of the mangrove forests and the surrounding landscape is an important factor in their ability to keep pace with sea-level rise.

\section{Introduction}

Mangrove forests live at the interface between terrestrial and marine environments and are likely to be threatened by increases in sea level associated with climate change. A study of mangrove extent over the last 10,000 years found long-term mangrove survival is unlikely beyond a sea-level rise threshold rate of 6.1 millimeters per year $(\mathrm{mm} / \mathrm{year}$; Saintilan and others, 2020). With projections of sea-level rise rates reaching more than $10 \mathrm{~mm} /$ year by 2100 (Church and others, 2013; Kopp and others, 2014), there is a need for modeling tools that can provide information to land managers and stakeholders about the resilience of mangrove resources under a range of sea-level rise scenarios.

Mangroves are recognized as critical ecosystems that provide habitat to a wide diversity of species and provide valuable ecosystem services to human populations. Remote island communities, such as Pohnpei, Federated States of Micronesia, are especially reliant on mangroves for food, fiber, and fuel (Naylor and others, 2002). These communities also benefit from flood protection that mangroves provide during cyclones and tsunamis (Danielsen and others, 2005; Dahdouh-Guebas and Jayatissa, 2009). Globally, mangroves are an important component of climate change mitigation because they remove and store more carbon from atmospheric carbon dioxide $\left(\mathrm{CO}_{2}\right)$ than any other tropical forested ecosystem (Donato and others, 2011). By understanding mangrove resilience to future sea-level rise, it is possible to evaluate how mangrove functions could change during this century. 
Interactions among biological, physical, and human-development factors determine how mangroves could respond to sea-level rise. For example, the suspended-sediment load in adjacent waters, freshwater influences on root growth, tidal range, the ability of mangroves to migrate inland or horizontally, and the baseline condition of the mangrove forest all affect vulnerability to sea-level rise (Krauss and others, 2014; Lovelock and others, 2015; MacKenzie and others, 2016). Mangroves can maintain the elevation of the forest floor relative to sea level through accretion processes that involve root growth, mineral sedimentation, soil compaction, and peat development (Krauss and others, 2014). Mangroves are also capable of migrating upslope to maintain their elevations relative to ocean levels. Hydrologic alterations due to roads and bridges can alter sediment processes that are crucial for accretion, however, in addition to physically blocking the upland migration of mangrove forests as sea-level rise increases flooding. A model for mangrove resilience must account for these interacting processes.

Although the literature is full of models for tidal marshes that project biogeomorphic changes with sea-level rise (Morris and others, 2002; Craft and others, 2009; Fagherazzi and others, 2012; Swanson and others, 2014; Langston and others, 2020), there are not equivalent models available for mangrove ecosystems. Mangrove models have generally focused on the dynamics of forest growth (Chen and Twilley, 1998, FORMAN; Berger and Hildenbrandt, 2000, KiWi; Jiang and others, 2012), physiology (for example, Asaeda and Kalibbala, 2009), or coastline evolution (for example, van Maanen and others, 2015). To our knowledge, there has not been an attempt to consider the influence of sea-level rise on the interaction of above- and belowground processes that affect mangrove resilience.
Our objectives were to develop a sea-level rise response model for mangrove forests that explicitly considers forest growth dynamics and belowground processes. The model developed was loosely based on existing models of tidal ecosystems (REM, Rybczyk and others, 1998; NUMAN, Chen and Twilley, 1999; WARMER, Swanson and others, 2014) and integrates key elements that influence soil elevation (for example, community composition, inundation frequency, organic sediment composition, mineral sediment composition, root growth, and tidal range) to determine the likely effects on mangrove extent and distribution given differing sea-level rise scenarios. Other objectives were to calibrate the mangrove sea-level rise model for Pohnpei, Federated States of Micronesia using extensive field datasets and to project changes in elevation and mangrove community composition under a range of sea-level rise scenarios to 2100 for seven drainage basins across Pohnpei. By including data for five of the most common Pacific island mangrove species in the model (Bruguiera gymnorrhiza, Rhizophora apiculata, Rhizophora stylosa, Sonneratia alba, and Xylocarpus granatum; fig. 1), we were also able to assess vulnerability at the species level for each basin and island-wide as well as understand likely responses for species not directly modeled.

Datasets used in the model developed to assess mangrove resilience to sea-level rise included data collected from soil cores, forest-inventory plots, SETs, and water-level gages around Pohnpei. Model calibration used a 400-year spin up period to establish conditions, followed by a 20 -year period comparing model performance to observed data (1999-2019), and finally an 80-year simulation period comparing four rates of sea-level rise to the end of the century. The effects of sea-level rise on mangrove species distribution and resilience were assessed, and model limitations and needed data discussed. 

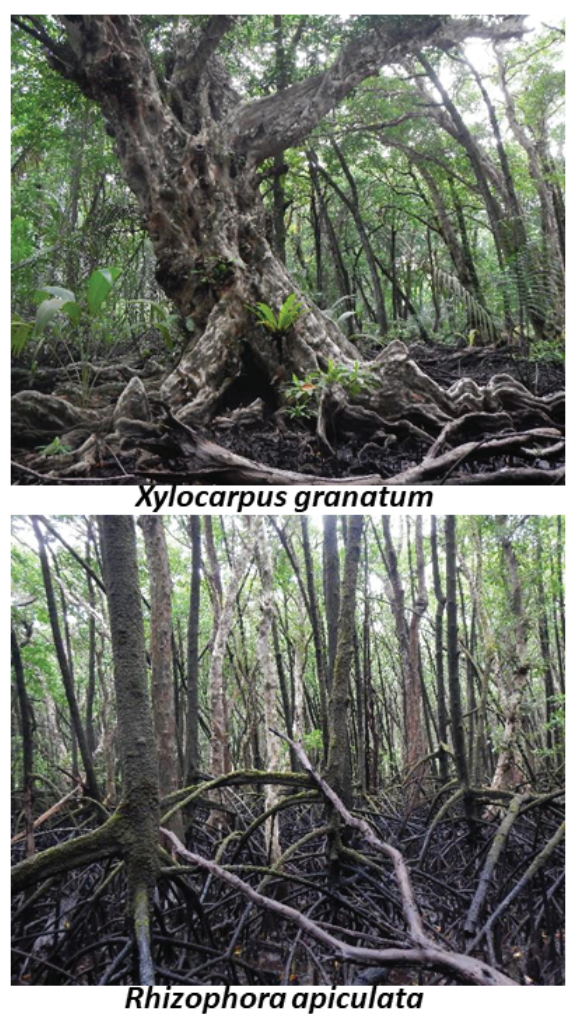

Rhizophora apiculata

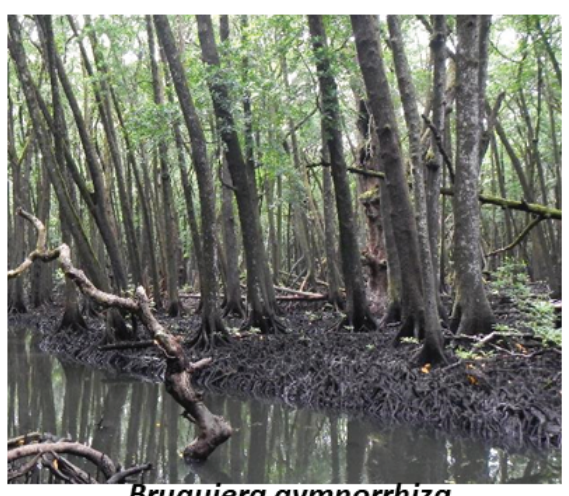

Bruguiera gymnorrhiza

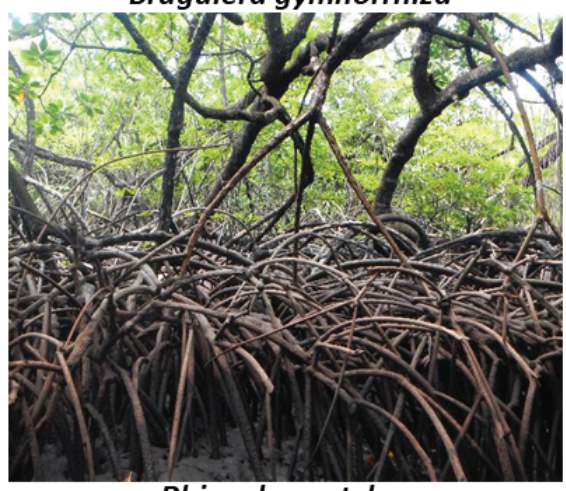

Rhizophora stylosa

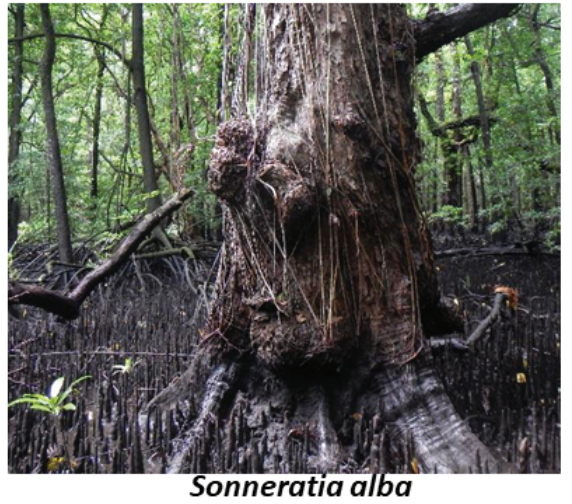

Sonneratia alba

Figure 1. Dominant mangrove species of Pohnpei, Federated States of Micronesia.

\section{Methods}

\section{Study Site}

The Federated States of Micronesia (FSM) comprises four island states approximately 4,000 kilometers $(\mathrm{km})$ southwest of Hawaii, just north of the equator. Pohnpei is the largest island state in the FSM at 346 square kilometers $\left(\mathrm{km}^{2}\right)$ and is home to about 35,000 people. The rugged topography rises steeply from the coast to the nearly 800-meter (m) summit of a dormant volcano. Pohnpei is ringed by coral reefs and $57 \mathrm{~km}^{2}$ of mangroves in the coastal lowlands. The extensive mangroves provide habitat to several endangered species such as the Pohnpei lorikeet (Trichoglossus rubiginosus) and fruit bats (Pteropus molossinus). Mangroves are important for human communities throughout the FSM; the fish, crabs, and firewood harvested from mangroves provide the equivalent of more than half of the annual household income (Naylor and others, 2002).

Pohnpei is characterized by a tropical rainforest climate. One of the wettest places on Earth, Pohnpei receives an average of 4,800 $\mathrm{mm}$ of rainfall each year and has no dry season (Lander and Khosrowpanah, 2004). The El NiñoSouthern Oscillation (ENSO) is responsible for the majority of the interannual variation in rainfall, with drier conditions in post El Niño years (Lander and Khosrowpanah, 2004). ENSO is also a strong driver of sea-level variation, and changes of \pm 30 centimeters ( $\mathrm{cm}$ ) are possible (Lander and Khosrowpanah, 2004).

\section{Model Description}

We developed a new process-based soil cohort model for understanding the vulnerability of mangroves to environmental change, especially sea-level rise (fig. 2). The model simulates changes in land-surface elevation in response to potential increases in sea level by estimating sediment accretion from inorganic inputs and biomass inputs from common mangrove species growing around Pohnpei (appendix 1, eq. 1). Mangrove biomass is estimated by fractional basal area, from which aboveground and belowground inputs are estimated using allometric relations and shoot:root ratios for each species, with additional belowground dynamics estimated from soil cores. Estimates of mass and density for each pool were used to calculate cohort volumetric contributions to depth by summation, and the total normalized by area to estimate land-surface elevation relative to mean sea level. The model uses estimates of elevation change relative to sea level to project changes in mangrove species' distribution around Pohnpei based on the optimal elevation ranges of various mangrove species. 


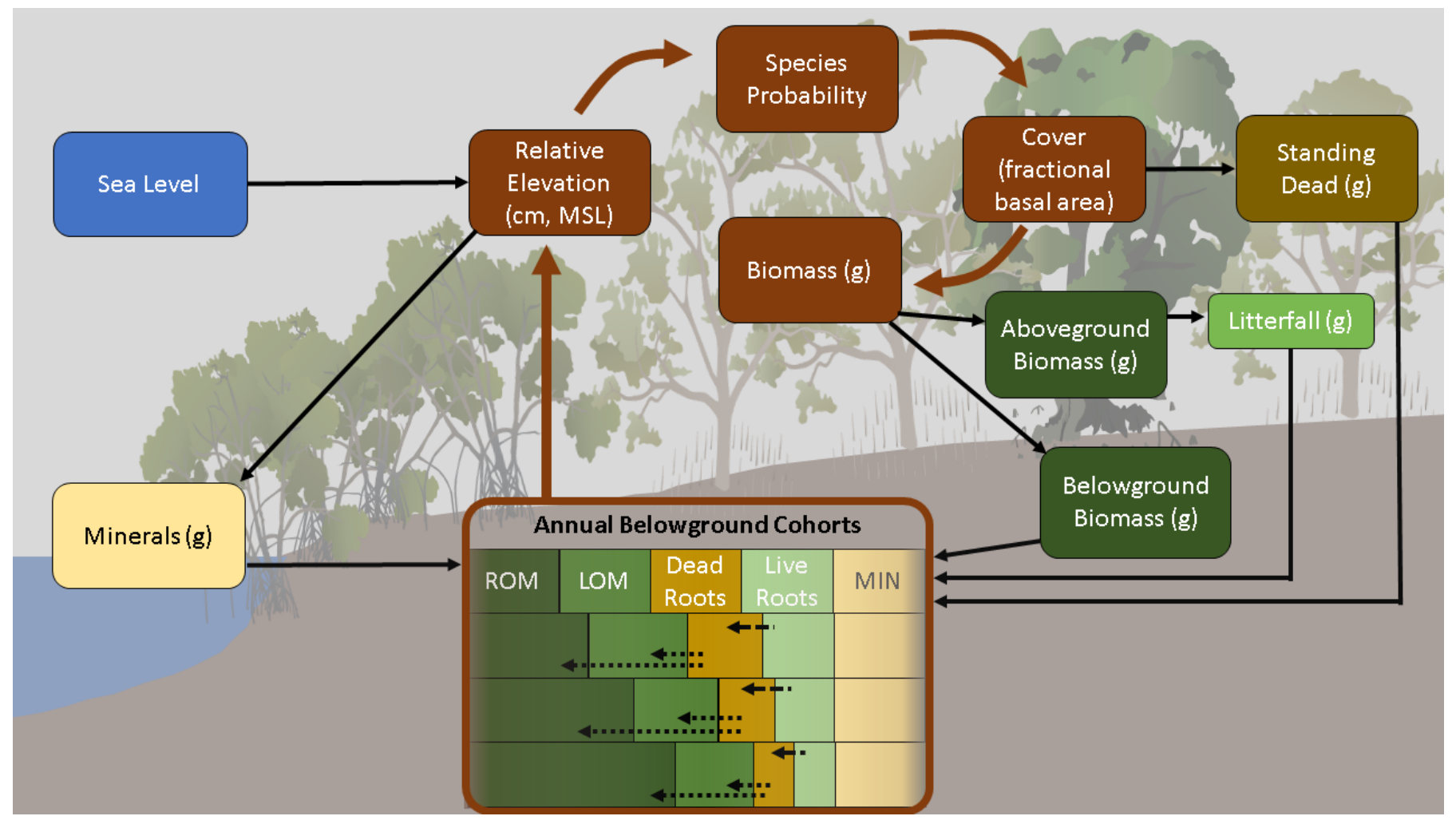

Figure 2. Approach to simulating surface-elevation relative to sea-level rise around Pohnpei, Micronesia, by modeling above and belowground organic and mineral pools and processes in mangrove forests.

The probability of species presence was determined from elevation relative to mean sea level (fig. 2). Fractional basal area for each species is held in living and standing dead pools. A negative change in fractional basal area, which results when surface elevation moves outside the optimal elevation range for a given species, adds fractional basal area to the standing dead pool. Both living and standing dead cover are converted to aboveground biomass using species-specific allometric equations. Standing dead biomass falls at a constant rate and is moved to the fallen dead pool where it undergoes decomposition. Litterfall and root turnover contribute to the labile (LOM) and refractory (ROM) soil organic pools, which are subject to loss by decomposition at differential rates. Rates of organic matter decomposition are tied to inundation period and slow with increasing depth in the soil column. Root density distribution by depth is determined by an exponential decay function, whereas mineral sediments are deposited in the surface cohort.

Each cohort represents both the age and depth of the soil and contains the organic and inorganic soil and root pools. A total of 80 age-depth cohorts were used in this model, transferring material to deeper cohorts at differential rates (for example, Rybczyk and others, 1998). The variable transfer rates were set such that there was higher temporal resolution in the upper soil layers and lower resolution in the deeper layers, where material accumulated (transfer rates of 1,2, 10, and 20 years/cohort, 20 cohorts in each). Using a constant number of cohorts was important for computational efficiency during multi-century model runs, where old, deep material changes very slowly.

\section{Community Composition Model}

A change in fractional basal area by species was modeled as a function of elevation and carrying capacity, in terms of fractional basal area (appendix 1, eq. 2). The probability distribution function for elevation by species was defined by field surveys and a rectangular kernel density ('density' function in R); the bandwidth of each species kernel was increased until the probability was smooth across the elevation gradient. Resultant areal density values for each species were normalized to range between 0 and 1 and describe the optimal elevation distribution for each species. A seeding rate $(\alpha)$ was set as a constant for each species (1 percent of carrying capacity); use of this constant assumed that each species could establish at any time step, provided favorable elevation and space. All cover lost at the beginning of the time step is transferred to the standing dead pool (appendix 1, eqs. 3 and 4 ). 
We used a logistic growth function to calculate the absolute growth rate needed to obtain 99-percent carrying capacity (in terms of basal area) in 60 years. To calculate relative growth rates, growth rates for each species (Devoe and Cole, 1998) were converted to fractional change in basal area by dividing by the reported mean diameter at breast height, averaged across species, and then differenced from the mean across species. The absolute rate was then scaled by relative growth rates for each species (table 1; appendix 1, eq. 5).

Relative species abundance in the model changes in terms of fractional basal area, which was then converted to aboveground biomass using species-specific equations (table 2). Over 300 forest inventory plots were used to develop the species-specific functional relationships between plot-level basal area and aboveground biomass (Peneva-Reed and Zhu, 2019). Aboveground biomass for individual trees was calculated from species-specific allometric equations. A more accurate two parameter allometric equation was used for those individuals that included a height measurement (table 3). Total basal area for each species was summed and divided by plot area to calculate fractional basal area. Across each plot, aboveground biomass was summed by species, log-transformed, and modeled as a function of log-transformed fractional basal area using multiple linear regression (table 3 ).

Table 1. Mangrove species growth-rate parameters in the model from Devoe and Cole (1998).

[Growth rate was calculated such that carrying capacity was at 99 percent after 60 years.]

\begin{tabular}{lccc}
\hline \multicolumn{1}{c}{ Species } & $\begin{array}{c}\text { Growth rate } \\
\text { (centimeters/year) }\end{array}$ & $\begin{array}{c}\text { Mean diameter } \\
\text { at breast height } \\
\text { (centimeters) }\end{array}$ & $\begin{array}{c}\text { Relative } \\
\text { growth rate } \\
\text { (centimeters/year) }\end{array}$ \\
\hline Bruguiera gymnorrhiza & 0.0854 & 25 & 0.35 \\
Rhizophora apiculata & 0.0988 & 16.6 & 0.25 \\
Rhizophora stylosa ${ }^{1}$ & 0.493 & 11 & 0.37 \\
Sonneratia alba & 0.0441 & 48.7 & 0.49 \\
Xylocarpus granatum & 0.0574 & 27 & 0.31 \\
\hline
\end{tabular}

${ }^{1}$ Data from Rhizophora mucronate.

Table 2. Fractional basal area to aboveground biomass linear regression coefficients and shoot:root ratios (Komiyama and others, 2008) for each mangrove species on Pohnpei, Federated States of Micronesia.

[Equation has the form: $\log ($ Biomass $\left.)=a(\log (\text { fractional basal area }))^{b}\right]$

\begin{tabular}{lcccc}
\hline \multicolumn{1}{c}{ Species } & a & b & R$^{2}$ & Shoot:Root \\
\hline Bruguiera gymnorrhiza & 4.44 & 1.11 & 0.74 & 2.91 \\
Rhizophora apiculata & 4.81 & 1.11 & 0.81 & 1.90 \\
Rhizophora stylosa & 6.21 & 1.11 & 0.78 & 1.90 \\
Sonneratia alba & 6.71 & 1.11 & 0.79 & 4.26 \\
Xylocarpus granatum & 8.09 & 1.11 & 0.95 & 3.00 \\
\hline
\end{tabular}

Table 3. Allometric equations estimating aboveground volume from tree diameter for most common mangrove species on Pohnpei, Federated States of Micronesia, from Cole and others (1999).

\begin{tabular}{|c|c|c|c|c|c|}
\hline \multirow[t]{2}{*}{ Species } & \multirow[t]{2}{*}{$\begin{array}{l}\text { Wood } \\
\text { density }\end{array}$} & \multicolumn{2}{|c|}{$\begin{array}{l}\text { Aboveground volume } \\
\text { (cubic meter) }\end{array}$} & \multicolumn{2}{|c|}{$\begin{array}{c}\text { Aboveground volume } \\
\text { with height } \\
\text { (cubic meter) }\end{array}$} \\
\hline & & a & b & $a_{1}$ & $b_{1}$ \\
\hline Bruguiera gymnorrhiza & 0.66 & $4.83 \mathrm{E}-05$ & 2.589 & 2.64E-05 & 0.992 \\
\hline Rhizophora apiculata & 0.885 & 5.79E-05 & 2.692 & $2.81 \mathrm{E}-05$ & 1.007 \\
\hline Rhizophora stylosa & 0.84 & 5.79E-05 & 2.692 & $2.81 \mathrm{E}-05$ & 1.007 \\
\hline Sonneratia alba & 0.63 & $1.28 \mathrm{E}-04$ & 2.359 & 4.49E-05 & 0.949 \\
\hline Xylocarpus granatum & 0.577 & $1.87 \mathrm{E}-04$ & 2.249 & $7.13 \mathrm{E}-05$ & 0.911 \\
\hline
\end{tabular}


To calculate belowground biomass, we used species-specific shoot:root ratios (Komiyama and others, 2008 and references therein); no value was available for $X$. granatum, so we assumed a moderate value of 3.0.

\section{Soil Cohort Model}

Species biomass (grams) was calculated from the living and dead fractional basal area at each timestep and divided into four pools: (1) living aboveground, (2) living belowground, (3) dead aboveground, and (4) dead belowground (fig. 3). Species-specific allometric equations (table 2) were used to convert the living fractional cover to the living aboveground biomass pool; a species-specific root-shoot ratio was used to estimate total belowground biomass. The fractional basal area for standing dead was converted to dead belowground litter, whereas the basal area for fallen dead was subject to export from the system proportional to time inundated, and the remainder was placed in the surface cohort of the wood litter pool (fig. 3).

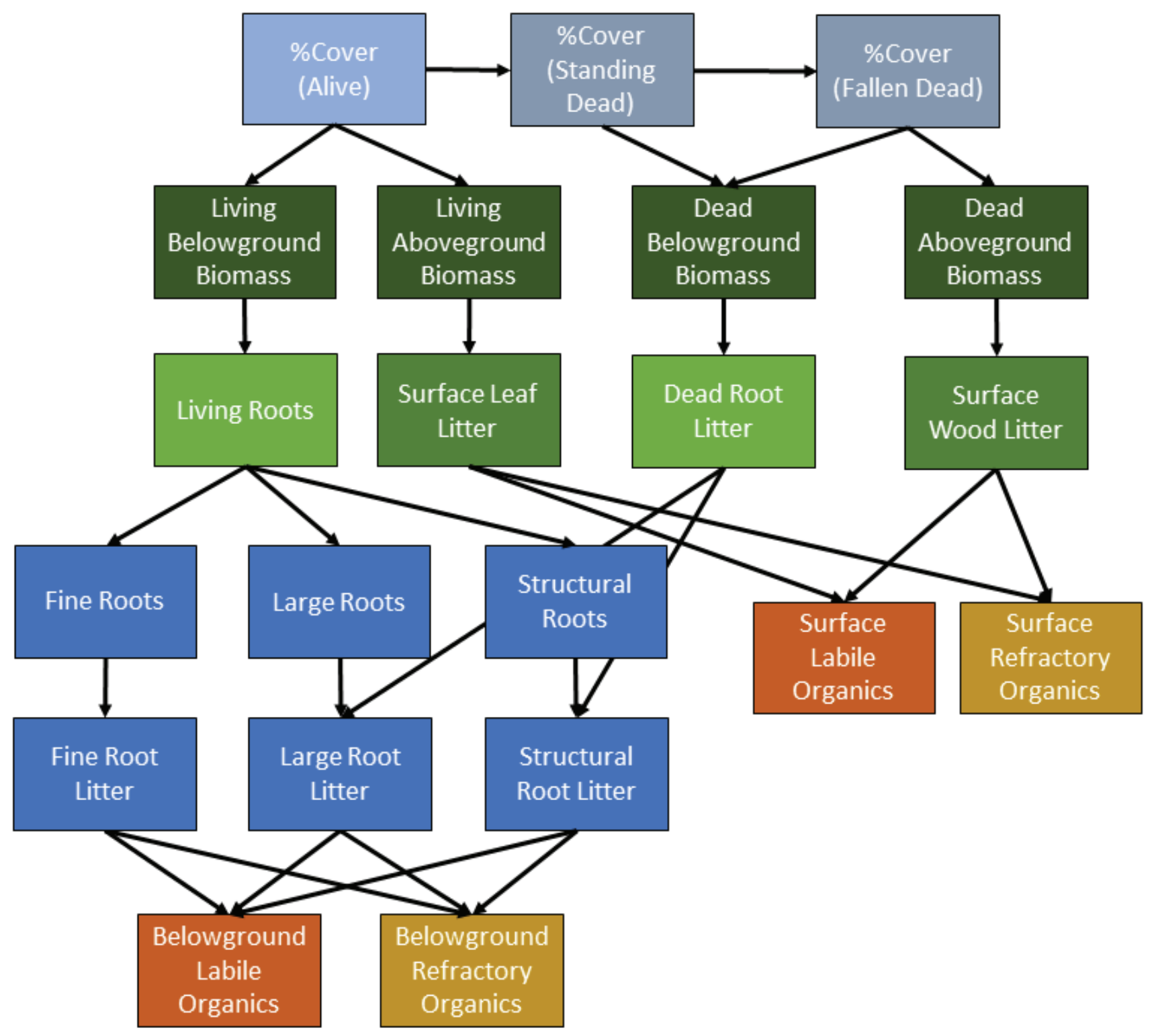

Figure 3. Model approach for how fractional mangrove basal area is apportioned to above and belowground living and dead biomass pools. 


\section{Surface Deposition}

Leaf and wood litter (grams) is separated into the surface pools of labile $\left(O_{l}\right)$ and refractory $\left(O_{r}\right)$ organic matter (appendix 1, eqs. 6 and 7). Leaf and wood litter comes from the aboveground living and fallen dead pools, such that wood (for example, branches) is assumed to fall at half of the leaf rate, and the export rate is assumed to be proportional to the percentage of annual inundation time (appendix 1, eqs 8 and 9).

Mineral sediments are deposited as a function of annual inundation duration. Tidal harmonics were derived from a long-term water-level gage (Pohnpei Harbor; Caldwell and others, 2015; http://uhslc.soest.hawaii.edu/data/) and used to define the functional relationship between inundation duration and elevation relative to mean sea level for one year. The amplitude of the functional relationship was calibrated to the mineral accumulation rate deduced from soil cores.

\section{Belowground Processes}

Belowground biomass (roots) were split into three size classes based on Cormier and others, 2015: structural (diameter more than 20 millimeters), large (2-20 millimeters), and fine (less than 2 millimeters). Structural-root volume was calculated using species-specific wood density (table 1), whereas large and fine roots were assumed to have a density of 0.2 grams per cubic centimeter $\left(\mathrm{g} / \mathrm{cm}^{3}\right.$; Kramer-Walter and others, 2016). Total living and dead roots mass (g) for all species was passed to the soil cohort module for calculation of total cohort volume and distributed across lower cohorts according to an exponential decay function (appendix 1, eq. 10). For structural roots, the decay coefficient $r 2$ was multiplied by 1.5 to better represent the pneumatophore root structures near the surface. The rates of organic matter decomposition $(\mathrm{g} / \mathrm{year})$ from the labile $\left(\operatorname{Loss}_{\mathrm{L}}\right)$ and refractory $\left(\operatorname{Loss}_{\mathrm{R}}\right.$ ) pools of each cohort were expressed as a function of percent time inundated and a decay constant for each type of organic matter (appendix 1, eqs. 11 and 12).

Root turnover, the process of living roots dying, was modeled as a two-step process. First, root turnover biomass was calculated as a fraction of living root biomass and distributed into dead root litter pools according to size class (fig. 3; appendix 1, eqs. 13-15). Each root size class had unique turnover rates informed by previous studies (large and fine roots; Cormier and others, 2015) and calibration (structural roots). The dead root litter that accumulated from the turnover process had the same density as living roots; this assumed that newly dead roots maintained their structure and volume for one year before beginning to decompose into particulate organic matter. Biomass in the dead root litter pool subsequently decomposes into particulate labile and refractory organic matter at different rates and as a function of annual percent inundation time, such that decomposition is slower deeper in the soil column as inundation increases. We assumed refractory decomposition is 100 times slower than labile decomposition. The fraction of labile material in roots was informed by a previous mangrove modeling study (Chen and Twilley, 1999). Dead roots that are created when a tree dies were treated separately from the dead roots generated from turnover in order to avoid unrealistic elevation gains from the rapid infusion of low-density organic material into the soil. Roots from standing and fallen dead trees were split into labile and refractory pools that lose mass at a pool-specific logarithmic decay rate and track the years since tree death (appendix 1, eqs. 16-18).

Bulk density of each cohort is calculated by fitting a modified version of a mixing model (Morris and others, 2016) to the soil-core interval data. We added a term for the mass of mineral and organics sediments overlying the cohort to account for the consolidation of sediments through time (appendix 1, eq. 19). Percent organic matter of the soil cohort was used with the mineral content to calculate bulk density, which in combination with the volume of living and dead roots, was used to calculate total cohort volume (appendix 1, eq. 20) and depth of the soil core (appendix 1, eq. 21). Consolidation of sediments proceeds both as a function of the mass of the overlying cohorts and as an increase in bulk density from the decomposition of organic matter.

\section{Calibration Datasets}

We selected seven representative sites on Pohnpei, Federated States of Micronesia, for modeling based on the availability of long-term accretion data derived from lead-210 dating (R. MacKenzie, U.S. Forest Service, written commun., August 15, 2018; fig. 4), which is used for dating materials up to about a century old (Appleby and Oldfield, 1978). Thirty 1-m long cores were used to calibrate the model. Each core was sectioned into 2-cm intervals and analyzed for dry bulk density and organic matter percent through loss-on-ignition. Average accretion, mineral accumulation rate, and organic accumulation rates for each site were used to calibrate the model, assuming a 75-year horizon (table 4). The soil-core data were also used to calculate the parameters in the mixing model (eq. 21) for estimating bulk density $\left(\mathrm{k}_{1}=0.145, \mathrm{k}_{2}=0.908, \mathrm{k}_{3}=-0.029\right.$; root mean squared error, RMSE $=0.072$; fig. 5); we assumed a maximum bulk density limit of $1.2 \mathrm{~g} / \mathrm{cm}^{3}$. We used an analysis of variance to test for site and hydrologic zone differences in soil-core elevation, accretion rate, and the organic and mineral accumulation rates. 


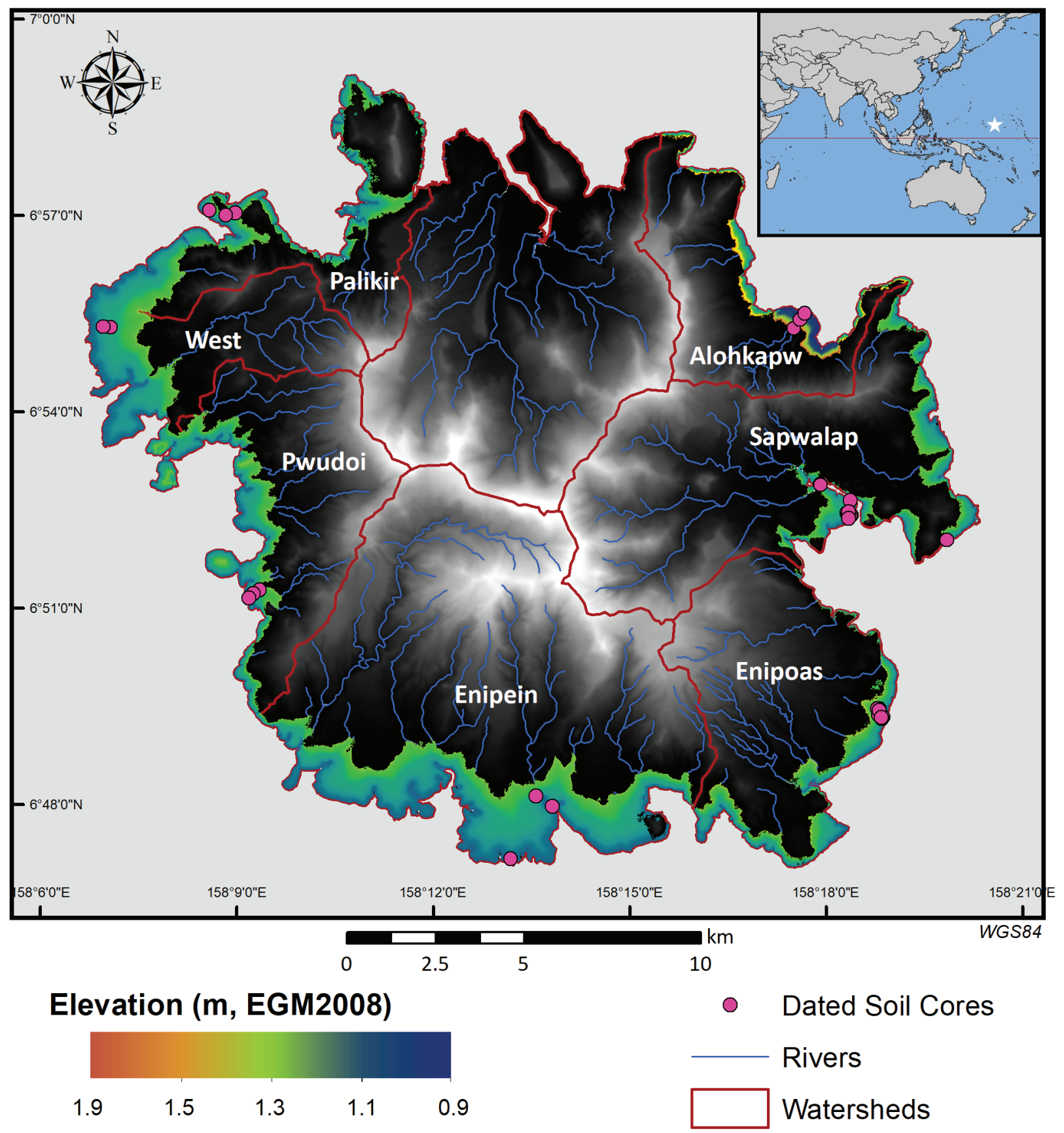

Figure 4. Location and digital elevation model of study sites around Pohnpei, Federated States of Micronesia, relative to large watersheds.

Water-level records from the long-term gage at the airport on Pohnpei were used to calculate mean sea level (MSL), mean high water (MHW) and mean low water (MLW) for 1983-2001, the most recent National Oceanic and Atomspheric Administration (NOAA) epoch. Pressure transducer water-level dataloggers (Solinst ${ }^{\circledR}$ Edge Jr.) were also deployed at three study sites (Enipoas, Enipein, Sapwalap), but only the loggers at Sapwalap and Enipein were recovered. The loggers were deployed just above the soil surface and recorded data in 12-minute intervals, from which the frequency and duration of high tides that inundated the mangrove forest (from July 7, 2016, to March 13, 2017) were determined. The data from the loggers and the airport gage were aligned, and MSL was estimated for each logger site by the MHW difference (appendix 1, eq. 22). For sites without water-level data, the MSL was assigned according to the nearest site with data (table 5). 
Table 4. Mean (standard error) soil-core accretion rates, organic and mineral accumulation rates, elevation, along with the regional mean sea-level estimate for study sites on Pohnpei, Federated States of Micronesia.

\begin{tabular}{lcccccc}
\hline \multicolumn{1}{c}{ Site } & $\begin{array}{c}\text { Soil } \\
\text { cores }\end{array}$ & $\begin{array}{c}\text { Accretion } \\
\text { (centimeters/ } \\
\text { year) }\end{array}$ & $\begin{array}{c}\text { Organic } \\
\text { accumulation } \\
\text { (grams/meter2/year) }\end{array}$ & $\begin{array}{c}\text { Mineral } \\
\text { accumulation } \\
\text { (grams/meter2/year) }\end{array}$ & $\begin{array}{c}\text { Elevation } \\
\text { (meters, } \\
\text { EGM2008 geoid) }\end{array}$ & $\begin{array}{c}\text { Mean sea level } \\
\text { (meters, } \\
\text { EGM2008) }\end{array}$ \\
\hline Alohkapw & 3 & $0.385(0.080)$ & $437.87(74.0)$ & $1,122.7(466.7)$ & $1.249(0.0298)^{\mathrm{a}}$ & 1.023 \\
Enipein & 2 & $0.293(0.099)$ & $366.6(99.1)$ & $331.9(68.7)$ & $0.843(0.066)^{\mathrm{ab}}$ & 0.816 \\
Enipoas & 8 & $0.277(0.034)$ & $347.6(38.4)$ & $144.0(19.1)$ & $1.038(0.029)^{\mathrm{ab}}$ & 0.905 \\
Palikir & 3 & $0.454(0.014)$ & $474.7(50.9)$ & $233.5(21.3)$ & $0.935(0.006)^{\mathrm{ab}}$ & 0.905 \\
Pwudoi & 3 & $0.221(0.066)$ & $345.1(97.9)$ & $122.3(34.4)$ & $0.859(0.078)^{\mathrm{b}}$ & 0.816 \\
Sapwalap & 9 & $0.390(0.118)$ & $5,497.9(181.0)$ & $544.3(163.6)$ & $1.175(0.071)^{\mathrm{ab}}$ & 0.905 \\
West & 2 & $0.152(0.027)$ & $271.5(91.5)$ & $70.6(5.5)$ & $1.075(0.017)^{*}$ & 0.905 \\
\hline
\end{tabular}

*Elevation estimated from digital elevation model at West; this was not included in the statistical analysis. Letters denote significant difference at alpha $=0.05$.

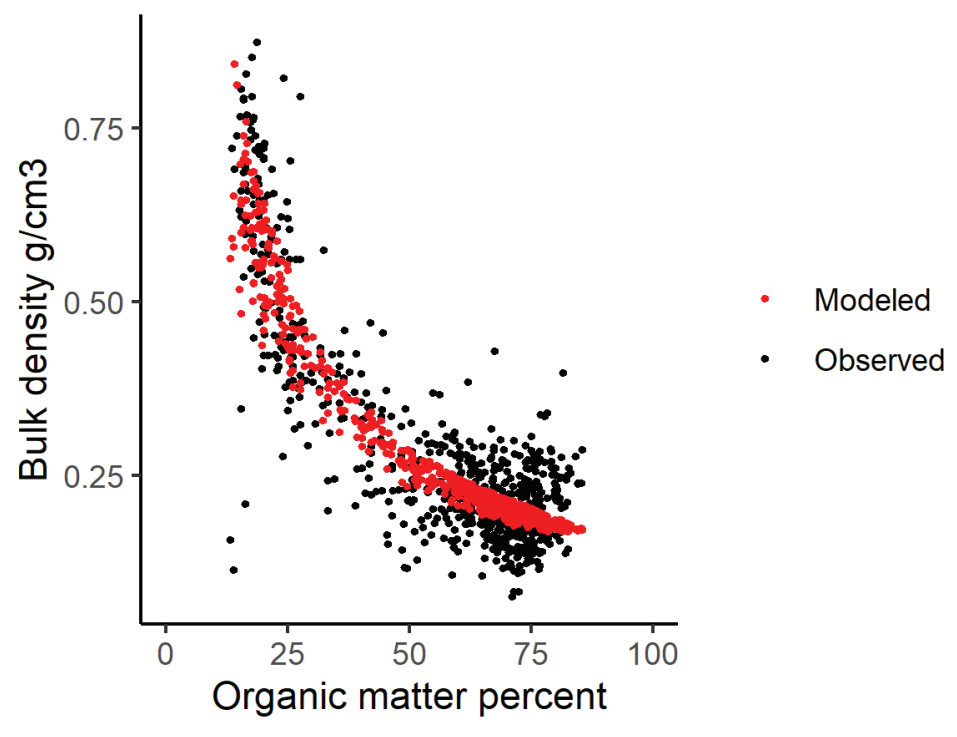

Figure 5. Relationship between organic matter percentage and bulk density from mangrove soil cores across Pohnpei, Federated States of Micronesia (from R. MacKenzie, U.S. Forest Service, written commun., August 15, 2018).
Table 5. Site elevation values for mangrove vulnerability to sea-level rise model for Pohnpei, Federated States of Micronesia, and root mean squared error (RMSE).

\begin{tabular}{lcc}
\hline \multicolumn{1}{c}{ Site } & $\begin{array}{c}\text { Distance from seaward } \\
\text { edge of mangrove forest } \\
\text { (meters) }\end{array}$ & RMSE \\
\hline Alohkapw & 859 & 0.275 \\
Enipein & 600 & 0.258 \\
Enipoas & 635 & 0.079 \\
Palikir & 600 & 0.375 \\
Pwudoi & 600 & 0.309 \\
Sapwalap & 600 & 0.277 \\
\hline
\end{tabular}


Elevation surveys were completed in February 2017 and April 2019 (Irwin and others, 2021). Temporary benchmarks were established outside the mangrove forest using a Trimble global navigation satellite system base station. We then used differential leveling to establish the elevation from the benchmark with the surface elevation table (SET) and soil-core locations at each study site. At each turning point along the leveling transect, the presence of each mangrove species within a 10-meter $(\mathrm{m})$ radius was recorded. We used the species-elevation data from 152 plots to derive probability distribution functions for each species, which in turn control the growth rate in the population model (fig. 6). We used the soil-core elevation to calibrate a site-specific mineral-accumulation function.

Digital elevation models (DEMs) were created for each site using transects of differential leveling data and the elevation profile from seaward to upland edge. We digitized the shore and upland edge of the mangrove forest with high resolution $(0.3 \mathrm{~m})$ WorldView 2 satellite image, and Euclidean distances from each edge were calculated as rasters. An elevation-profile transect was generated using a subset of data from Enipoas, Enipein, Palikir, and Pwudoi (fig. 4). Elevation profiles of the transect were generated using a general additive model (GAM) spline and the relationship between elevation and distance from the seaward edge (fig. 7). We used the relative width of the mangrove forest to extrapolate the elevation profile GAM model across the study site (appendix 1, eq. 23).

For each site, we used an optimizing function to determine the maximum width, $\mathrm{W}_{\mathrm{m}}$, value that resulted in a DEM with the lowest RMSE when compared with the elevation points for that site, constraining $\mathrm{W}_{\mathrm{m}}$ between 600 and $950 \mathrm{~m}$. Model accuracy varied by site (table 5); the average RMSE for all the sites was $0.26 \mathrm{~m}$.

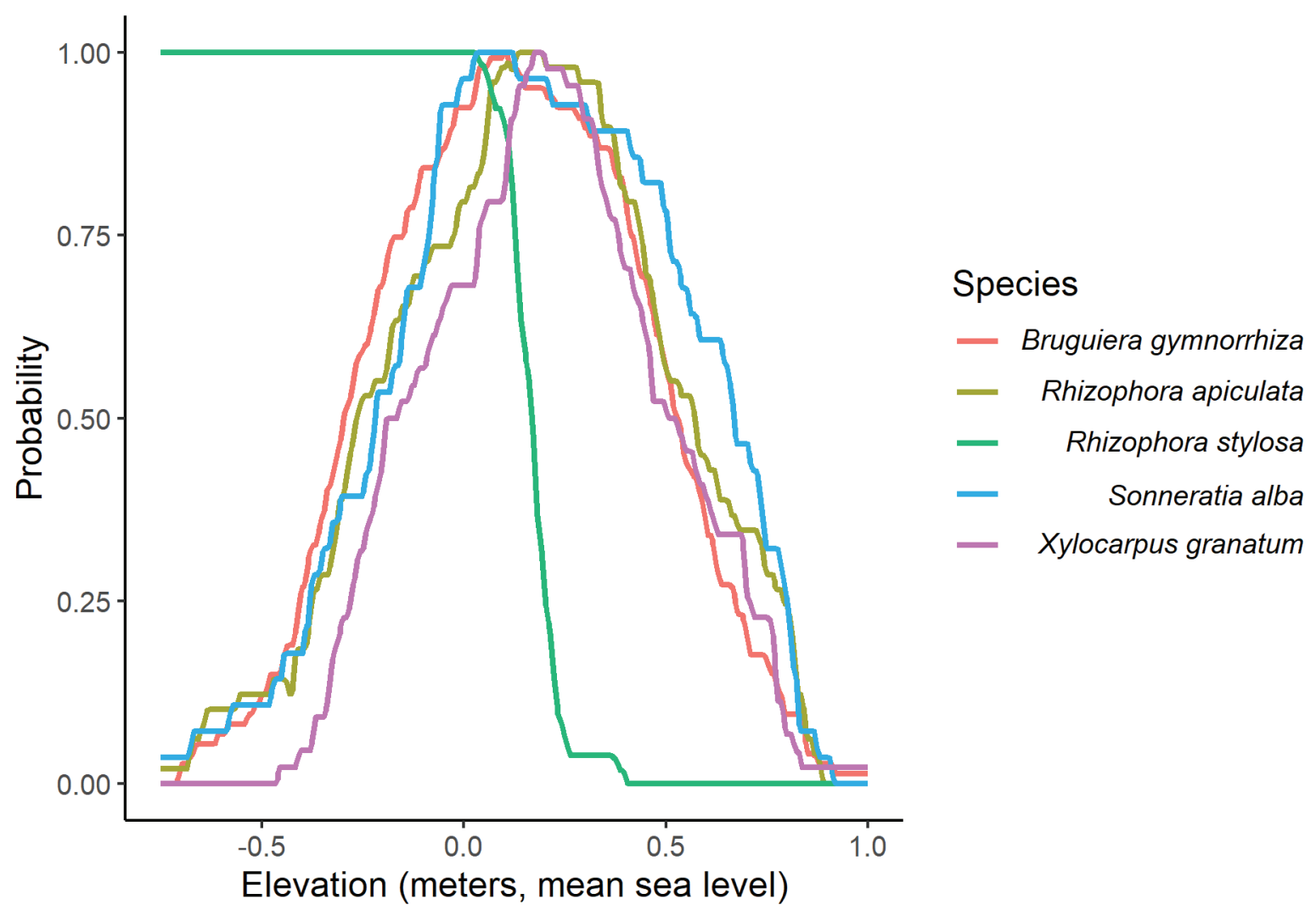

Figure 6. Elevation probability distribution functions for five common mangrove species on Pohnpei, Federated States of Micronesia. 


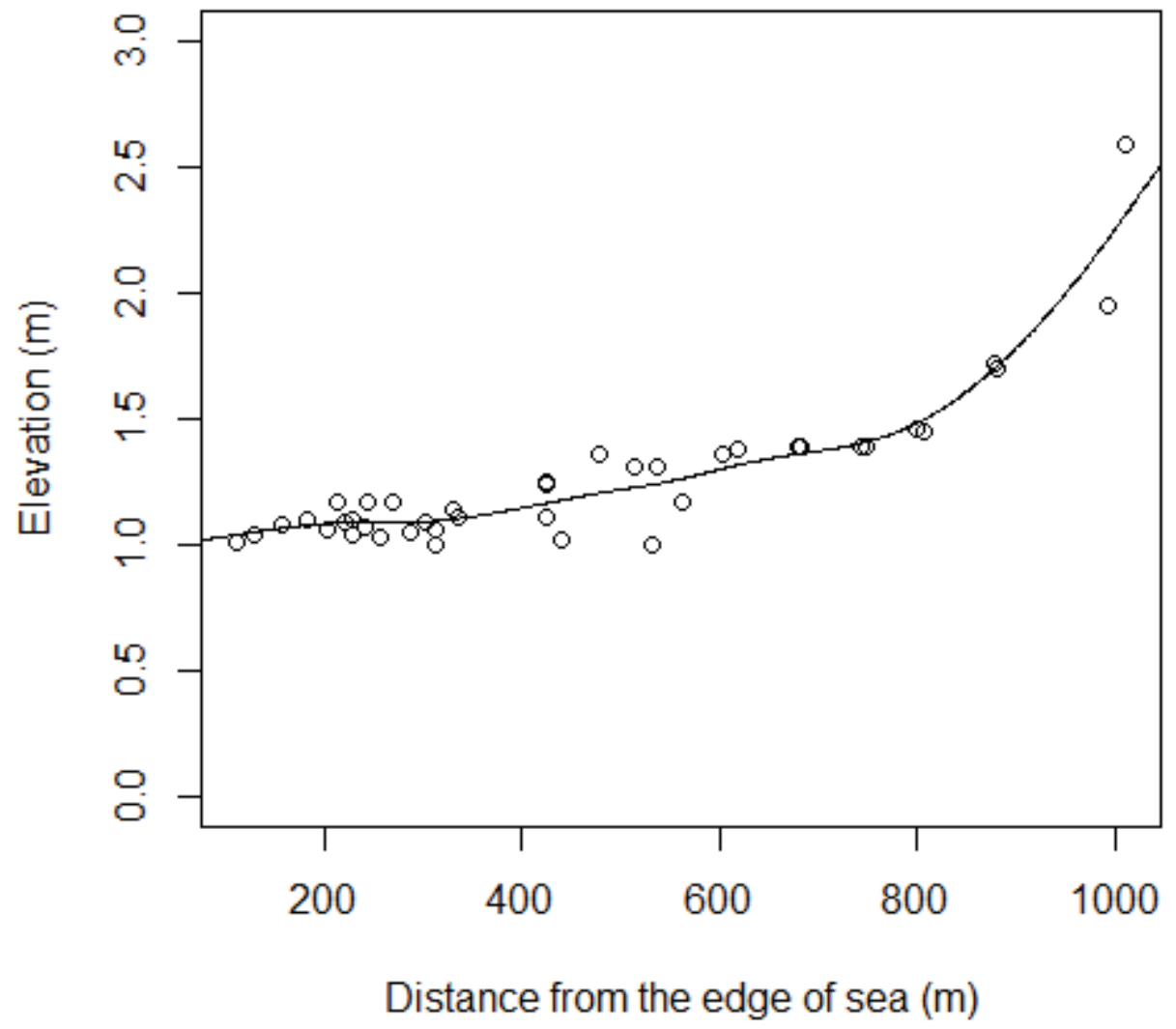

Figure 7. Land-surface elevation profile with distance, in meters $(\mathrm{m})$, from the seaward edge of the mangrove forest, derived from elevation leveling datasets, February 2019, at northern and southern study sites, Pohnpei, Federated State of Micronesia.

We used a multi-step calibration scheme to estimate several important parameters while preserving site differences (table 6). We allowed three parameters to change for site-specific model calibrations. First, the mineral accumulation rate was calibrated to the data from the soil cores. Second, carrying capacity, here defined as fractional basal area, was calculated as the 95th percentile from field surveys in each region. The litter deposition rate was set to 2 percent of aboveground biomass, a value that produced approximately 8,800 kilograms per hectare ( $\mathrm{kg} / \mathrm{ha}$ (R. Hauff, unpublished data, in Gleason and Ewel, 2002). Finally, we calibrated the labile decomposition coefficient for inundation $\left(k_{l}\right)$ to minimize the difference in modeled and observed elevation after 100 years in a model simulation that used the historic sea-level rise rate $(3.75 \mathrm{~mm} /$ year $)$ and initial elevations estimated from soil-core accretion rates. Modeled values of all roots, living roots (fine and large), and ratio of dead:live roots were compared with values from Cormier and others (2015); for all sites, these values were within the range of literature values (appendix 2). The proportion of structural roots was calibrated such that the living fine and large root mass pools were less than the value provided in Cormier and others (2015); we assumed structural roots were not incorporated in the soil cores of that study. The parameters that control root collapse $\left(l_{h}, r_{h}, d_{b}, d_{l}\right)$ were constrained by limiting the elevation loss of a dead forest to a maximum of $10 \mathrm{~mm} /$ year, the rate of soil collapse observed in a harvest mangrove stand (Krauss and others, 2010). The model only considers elevation and does not directly consider the potential effects of salinity or macronutrients on organic deposition or decomposition; we assumed that site-specific values of carrying capacity (table 6) and the organic accumulation rate reflect these factors. A 400-year model spin-up period, using sea-level rise rates equal to the mean soil-core accretion rates and three initial land-surface elevations $(5,15,35 \mathrm{~cm}$ relative to MSL), was used to assess model accuracy by comparing modeled and observed vertical accretion, mineral accumulation, and organic matter accumulation rates (appendix 2). By using the mean accretion rates to calibrate the model, we are assuming that these historic (75 year) accretion rates represent a forest in steady state with its environment. 
Table 6. Model parameters for the seven mangrove study sites, Pohnpei, Federated States of Micronesia.

[Parameters with no values were held constant across sites. Abbreviations: —, not applicable; cm, centimeters]

\begin{tabular}{|c|c|c|c|c|c|c|c|c|c|}
\hline Parameter & Symbol & Alohkapw & Enipein & Enipoas & Palikir & Pwudoi & Sapwalap & West & Source \\
\hline Structural root fraction & $\mathrm{y}_{1}$ & 0.90 & - & - & - & - & - & - & $\begin{array}{l}\text { Calibration, Cormier and } \\
\text { others, } 2015\end{array}$ \\
\hline Fine root fraction & $\mathrm{y}_{2}$ & 0.27 & - & - & - & - & - & - & Cormier and others, 2015 \\
\hline $\begin{array}{l}\text { Carrying capacity } \\
\text { (fractional basal area) }\end{array}$ & $\mathrm{k}$ & 0.008 & 0.011 & 0.0092 & 0.0073 & 0.0065 & 0.011 & 0.0061 & $\begin{array}{l}\text { Peneva-Reed and Zhu, 2019; } \\
\text { 95th percentile }\end{array}$ \\
\hline Reseeding rate & $\alpha$ & 0.01 & - & - & - & - & - & - & Constant, this study \\
\hline Root growth coefficient & $\mathrm{r} 2$ & 0.1 & - & - & - & - & - & - & $\begin{array}{l}\text { Calibrated to } 80 \mathrm{~cm} \text { depth, } \\
\text { Ono and others, } 2015\end{array}$ \\
\hline Fine root turnover & $\mathrm{kr}$ & 0.1 & - & - & - & - & - & - & Constant, this study \\
\hline Large root turnover & $\mathrm{km}$ & 0.08 & - & - & - & - & - & - & Cormier and others, 2015 \\
\hline Structural root turnover & $\mathrm{kt}$ & 0.015 & - & - & - & - & - & - & $\begin{array}{l}\text { Calibration, informed by } \\
\text { Cormier and others, } 2015\end{array}$ \\
\hline Fine root labile fraction & fc1 & 0.75 & - & - & - & - & - & - & Chen and Twilley, 1999 \\
\hline $\begin{array}{l}\text { Large root labile } \\
\text { fraction }\end{array}$ & fc2 & 0.80 & - & - & - & - & - & - & Chen and Twilley, 1999 \\
\hline Leaf refractory fraction & $\operatorname{lr}$ & 0.15 & - & - & - & - & - & - & Chen and Twilley, 1999 \\
\hline $\begin{array}{l}\text { Litter deposition } \\
\text { fraction }\end{array}$ & ld & 0.02 & - & - & - & - & - & - & $\begin{array}{l}\text { Constant. Informed by R. } \\
\text { Hauff unpubl. data, in } \\
\text { Gleason and Ewel, } 2002\end{array}$ \\
\hline $\begin{array}{l}\text { Labile decomposition } \\
\text { coefficient for } \\
\text { inundation }\end{array}$ & $\mathrm{kl}$ & 11.46 & 6.93 & 7.60 & 8.19 & 7.78 & 5.75 & 9.08 & Core calibration \\
\hline $\begin{array}{l}\text { Labile maximum loss } \\
\text { rate per year }\end{array}$ & klx & 0.90 & - & - & - & - & - & - & Constant, this study \\
\hline $\begin{array}{l}\text { Refractory } \\
\text { decomposition } \\
\text { coefficient for } \\
\text { maximum loss rate }\end{array}$ & $\mathrm{krc}$ & 100 & - & - & - & - & - & - & Constant, this study \\
\hline Dead fall rate & $\mathrm{df}$ & 0.10 & - & - & - & - & - & - & Constant, this study \\
\hline Half-life of labile roots & $1_{\mathrm{h}}$ & 10 & - & - & - & - & - & - & Constant, this study \\
\hline $\begin{array}{l}\text { Half-life of refractory } \\
\text { roots }\end{array}$ & $\mathrm{r}_{\mathrm{h}}$ & 25 & - & - & - & - & - & - & Constant, this study \\
\hline Loss rate of root mass & $\mathrm{d}_{\mathrm{l}}, \mathrm{d}_{\mathrm{r}}$ & 0.5 & - & - & - & - & - & - & Constant, this study \\
\hline
\end{tabular}

At Sapwalap and Enipoas, we used a long-term (1999-2019) SET record to independently validate the model. At each site, there are three replicate SETs deployed in fringe, riverine, and interior hydrologic zones. Using the differential elevation data, the absolute elevation of each pin measurement was calculated relative to the Earth Gravitational Model of 2008 (EGM2008) datum, and the elevation in 1999 was determined. We used a 400-year model spin-up period to establish the mean initial soil profile and mangrove community at the mean elevation of each group of SETs. We used mean annual water level from the Pohnpei Harbor gage to calculate the annual change in sea level that was used to drive the model. We then compared the average modeled and observed accretion rates for the 20-year period (1999-2019).

To generate spatial results, we used the model to simulate a range of initial elevations and interpolated the results of fractional species cover across the 10-m resolution DEM in 10 -year intervals. Again, we used a 400 -year model spin-up to develop the forest and soil profile, holding the initial elevation constant and the rate of sea-level rise to zero. The sea-level rise scenarios were simulated after the spin-up period. 


\section{Sea-Level Rise Scenarios}

We used four future sea-level rise scenarios to assess the relative vulnerability of mangrove forests around Pohnpei. Relative to 2020, the representative concentration pathway (RCP) scenarios 4.5 and 8.5 from the IPCC project 37 and $67 \mathrm{~cm}$ of sea-level rise, respectively, by 2100 (Church and others, 2013; fig. 8). To illustrate model sensitivity, we included a moderate scenario of $52 \mathrm{~cm}$ by 2100 . The AR5 IPCC report did not consider potential instability of Antarctic ice sheets, so we also included a more extreme scenario by adding $50 \mathrm{~cm}$ to the RCP 8.5 scenario, resulting in a $117 \mathrm{~cm}$ sea-level increase by 2100 (fig. 7). In addition to sea-level rise, we included a constant $0.074 \mathrm{~mm} /$ year rate of subsidence, as estimated from deep soil-core data by J. Ellison (University of Tasmania, written commun., July 10, 2019).

Wetlands developing under larger tidal ranges tend to demonstrate increased resilience to sea-level rise through a greater capacity to build soil-surface elevations vertically (Kirwan and others, 2010), and also, they often have more time before undergoing submergence due to sea-level rise, especially if positioned at a distance inland (Lovelock and others, 2015). The El Niño-Southern Oscillation (ENSO) exerts control over interannual variation in sea level across the equatorial Pacific, such that El Niño periods lower sea levels around Pohnpei and La Niña events drive water levels higher. We fit a second-order polynomial to the 45-year record of mean sea level from Pohnpei to deduce the local trend in sea-level rise. We then fit a Weibull distribution to the residuals from the regression, which represent the recent historic influence of ENSO, storms, and long-period lunar nodal harmonics. We ran 100 Monte Carlo simulations for each sea-level rise scenario and calculated the annual average elevation and species cover area for those at greater than 15 -percent cover.
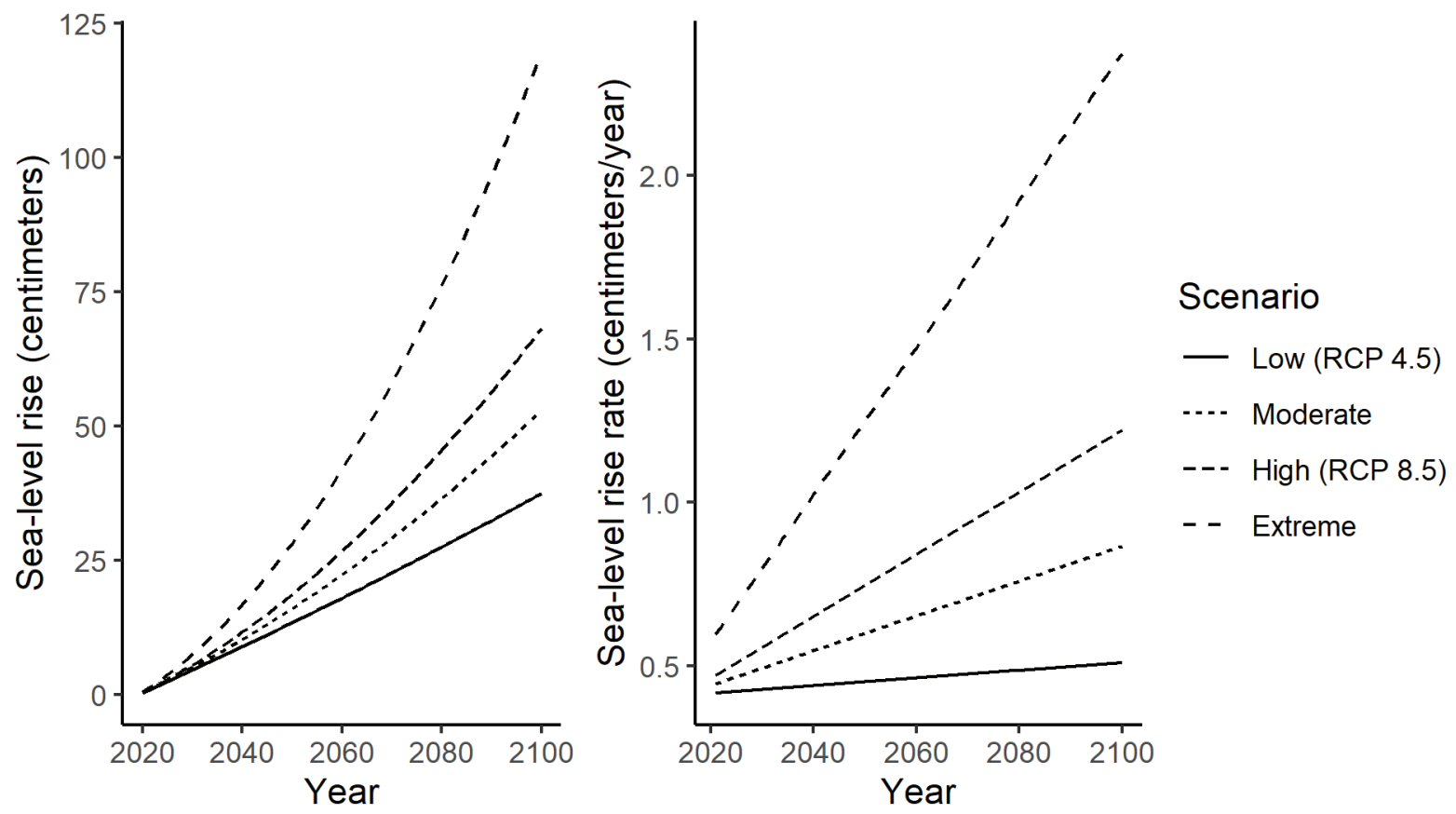

Figure 8. Sea-level rise scenarios simulated for 2020-2100 used to assess mangrove vulnerability on Pohnpei, Federated States of Micronesia. 


\section{Results}

Within sites there was a large amount of variation in the vertical accretion and accumulation rates; as a result, elevation was the only factor that was significantly different among sites $\left(\mathrm{F}_{5,24}=3.79, \mathrm{p}=0.011\right)$, with Alohkapw higher than Enipein $(\mathrm{p}=0.037)$ and Pwudoi $(\mathrm{p}=0.048)$. There were no significant differences in any of the factors we tested across hydrologic zones (fringe, interior, riverine).

Independent model validation at Sapwalap and Enipoas showed good agreement between SET measurements and model projections (fig. 9). Across Sapwalap fringe, interior, and riverine SETs, accretion rates averaged $2.28 \mathrm{~mm} /$ year (range: 0.06-4.66 mm/year). Using the average initial elevation from each group of SETs, the model projected an average accretion rate of $2.15 \mathrm{~mm} /$ year for the 20 -year simulation (1999-2019), a difference of 5.7 percent from measured values. The average SET accretion rate at Enipoas was $1.56 \mathrm{~mm} /$ year (range: $0.55-2.71 \mathrm{~mm} /$ year), and the model projected an average accretion rate of $1.94 \mathrm{~mm} /$ year, a difference of 19.7 percent from the measured rate.

During the next 80 years $(2020-2100)$, the model projected average elevation relative to MSL decreased at all sites (fig. 10); however, mangrove community composition was projected to be broadly resilient to high rates of sea-level rise until about 2060 (figs. 11-17). Only in the second half of the century at high or extreme rates of sea-level rise were large changes in elevation or community composition projected (figs. 11-13). Areas on the west side of the island were the most vulnerable to sea-level rise and included the West region; it was projected to lose modest amounts (less than 25 percent) of mangrove area by 2100 under the moderate sea-level rise scenario (fig. 11). The West region was especially vulnerable because of its low mineral and organic accumulation rates (table 4); however, the lack of any elevation data for the DEM or the soil cores in that region increased the projected model uncertainty. Sapwalap and Alohkapw had the highest mineral accumulation rates from the soil cores (table 4), which resulted in the model showing greater resilience to sea-level rise. Enipein also showed resilience, maintaining mangrove cover through 2100 under the $67 \mathrm{~cm}$ sea-level rise scenario. Under the extreme, $117 \mathrm{~cm}$ sea-level rise scenario, area suitable for mangrove was projected to be lost by 2100 across all sites (figs. 11-13).

The trends in changes of community composition were similar across sites; higher rates of sea-level rise stimulated more rapid increases in the cover of flood-tolerant species (figs. 12, 13). High proportions of B. gymnorrhiza and $R$. apiculata were projected initially at all sites, which aligns with field-survey data of these broadly distributed species. Xylocarpus granatum grows in the upper end of the tidal zone and initially was the third most common species in several regions; however, the model projected it to decrease in cover in all scenarios. Sonneratia alba and $R$. stylosa are the most flood-tolerant species; $R$. stylosa is generally restricted to the coastal edges of the forest, whereas $S$. alba is more broadly distributed. At most sites and under all sea-level rise scenarios, $S$. alba increased slightly in cover for about $30-40$ years before dropping in prevalence. Rhizophora stylosa increased in cover across all sites and sea-level rise scenarios, except at Alohkapw where it gradually decreased from a relatively high amount of cover. The projected transition to $R$. stylosa was responsible for the maintenance of total mangrove cover at Enipein, Palikir, and Sapwalap under the 67-cm sea-level rise scenario (fig. 16). 


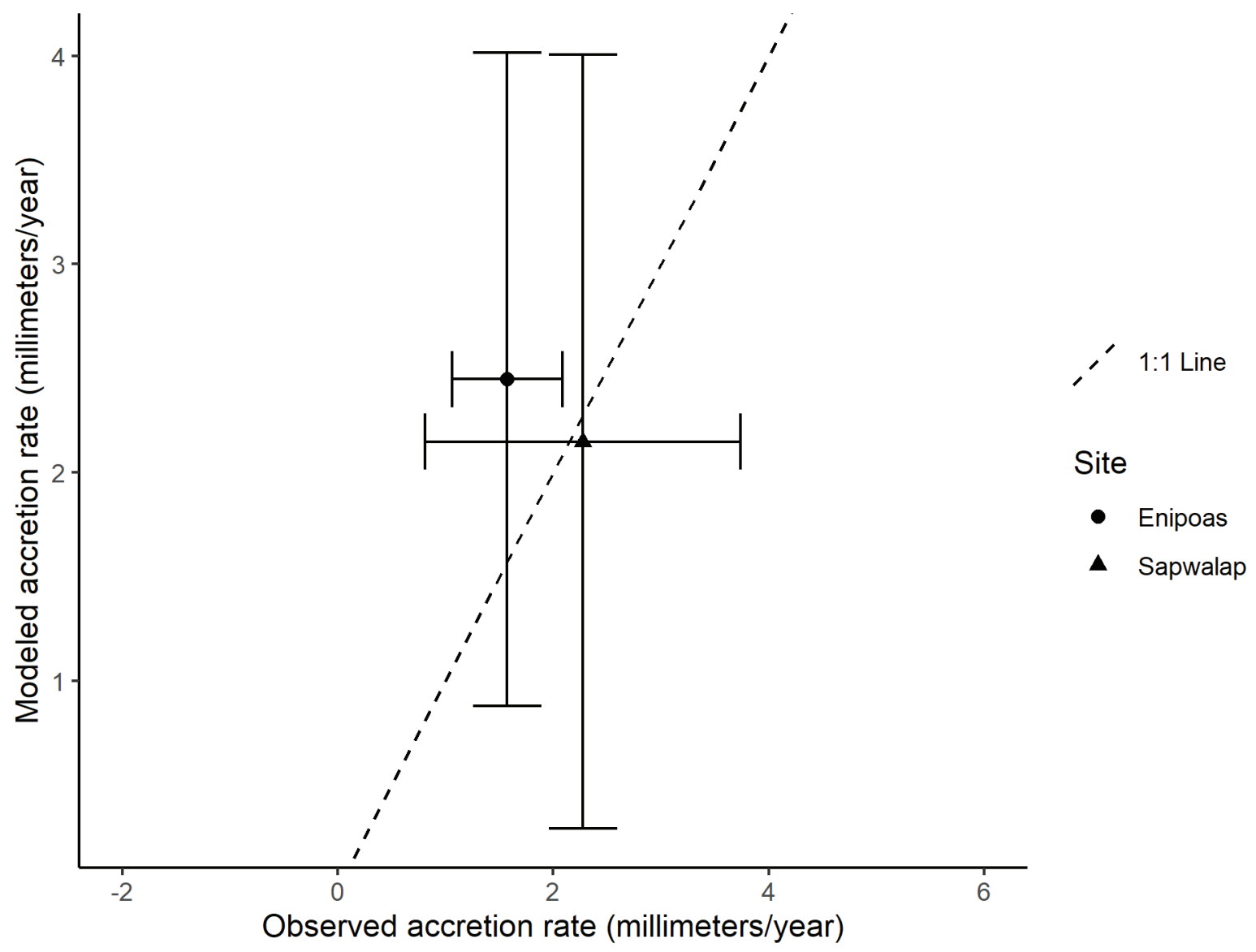

Figure 9. Mean ( \pm standard error) observed and modeled accretion rates during the 20 -year validation period (1999-2019) for two sites with data from surface-elevation tables, Pohnpei, Federated States of Micronesia. 


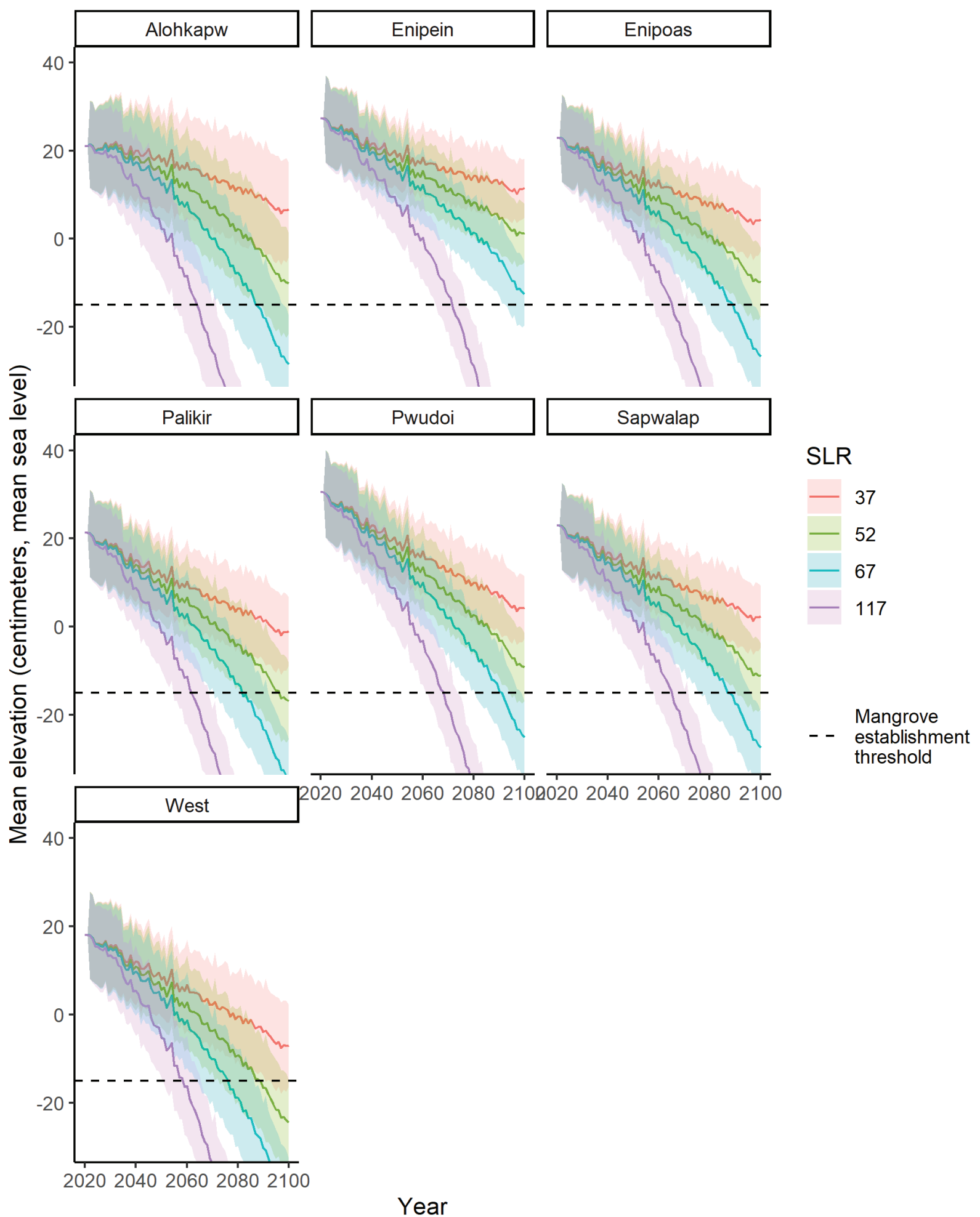

Figure 10. Mean ( \pm standard deviation) elevation (relative to mean sea level) for the seven study sites on Pohnpei, Federated States of Micronesia, under four sea-level rise scenarios from 2020 to 2100 based on global emission scenarios. 


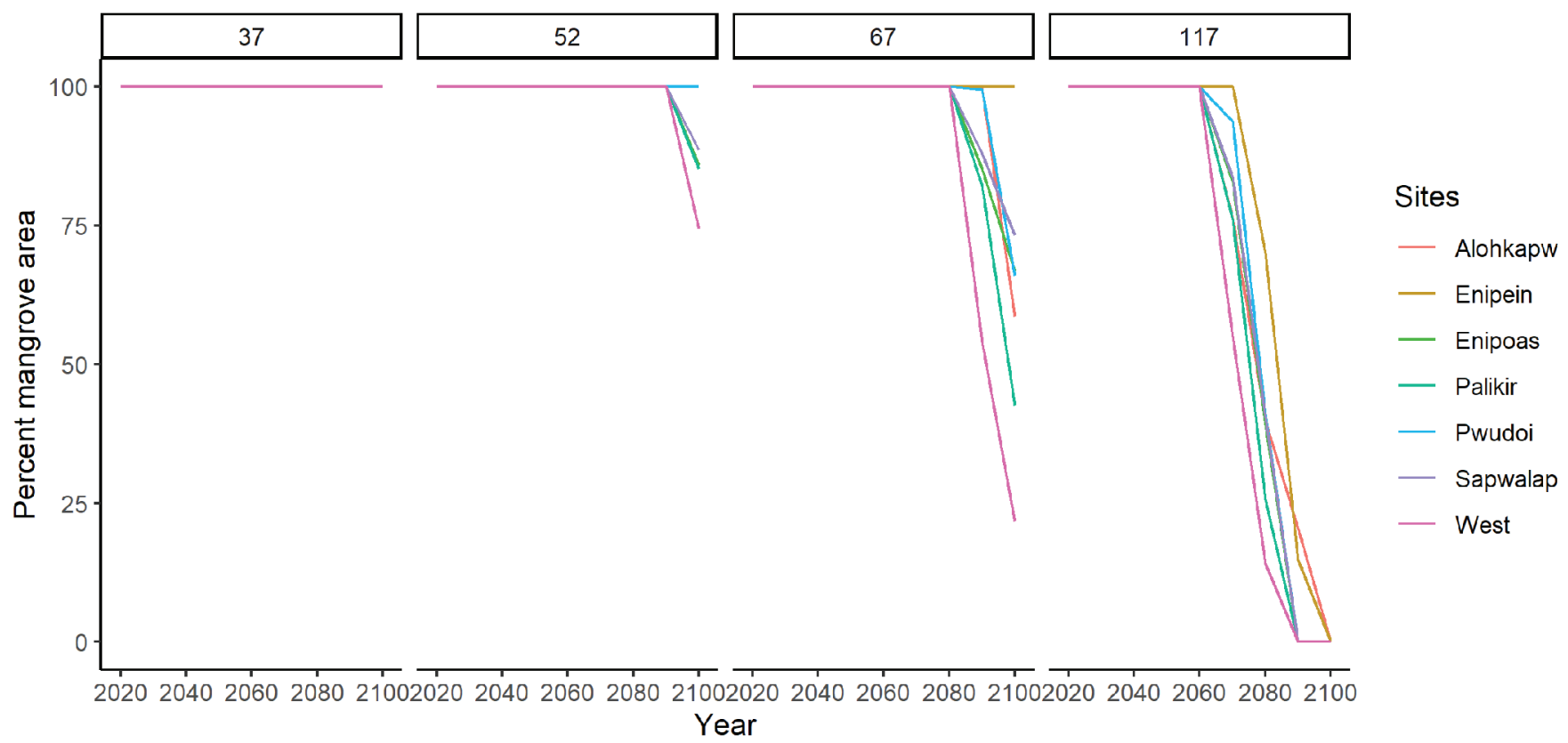

Figure 11. Average mangrove area (percent of initial) for each region on Pohnpei, Federated States of Micronesia, under sea-level rise scenarios $(37,52,67$, and $117 \mathrm{~cm}$ by 2100) from 2020 to 2100 . 

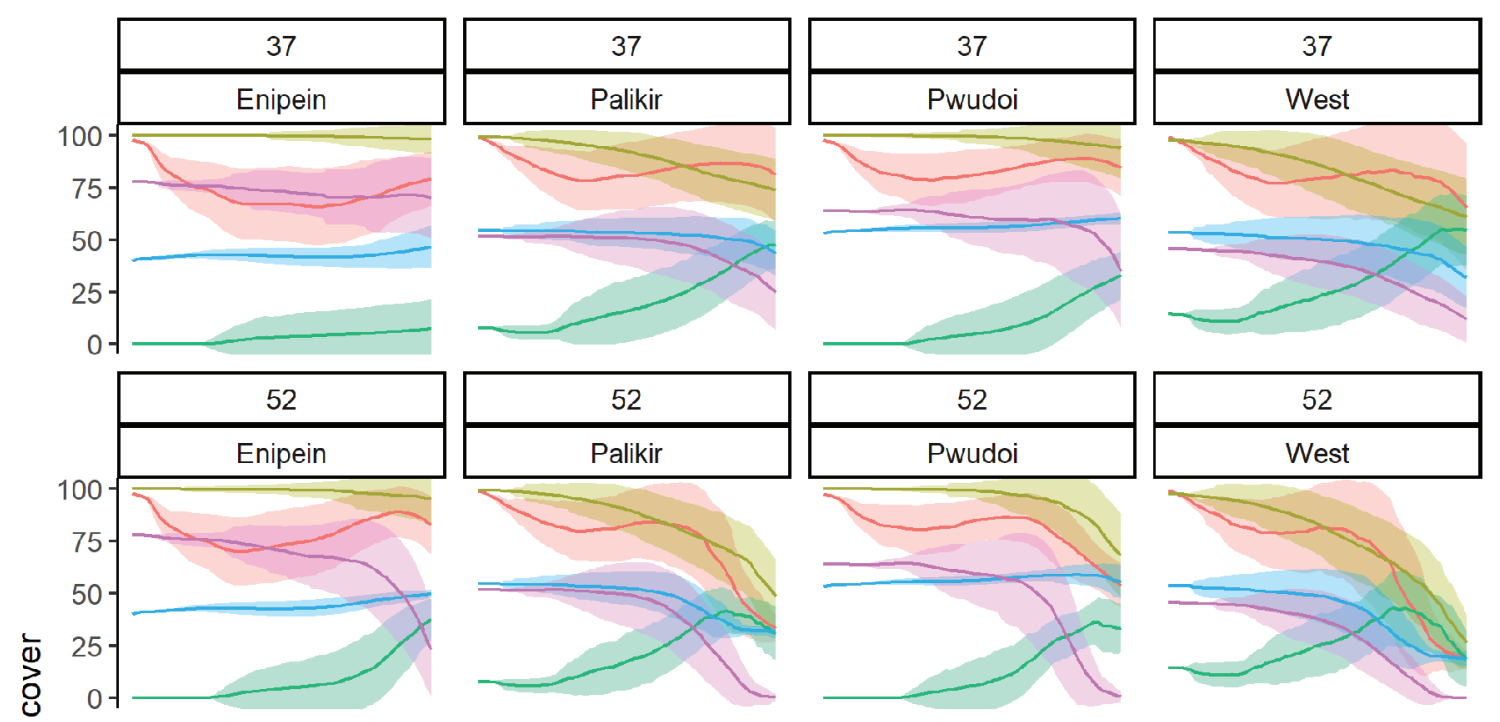

Species
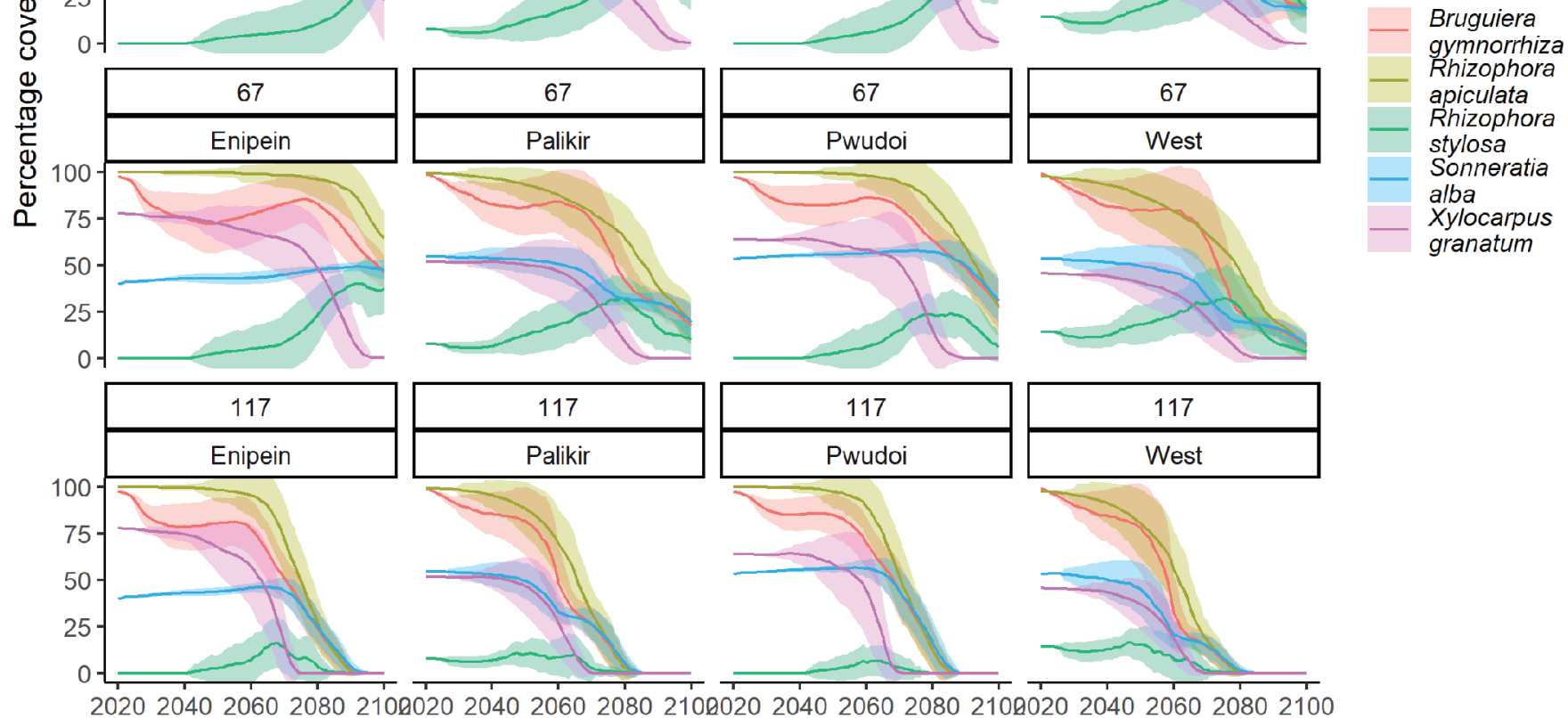

Year

Figure 12. Percentage ( \pm standard deviation) of the Enipein, Palikir, Pwudoi, and West study areas on Pohnpei, Federated States of Micronesia, covered by each mangrove species projected to have more than15-percent cover under low $(37 \mathrm{~cm})$, moderate $(52 \mathrm{~cm})$, high $(67 \mathrm{~cm})$, and extreme $(117 \mathrm{~cm})$ sea-level rise scenarios from 2020 to 2100. 

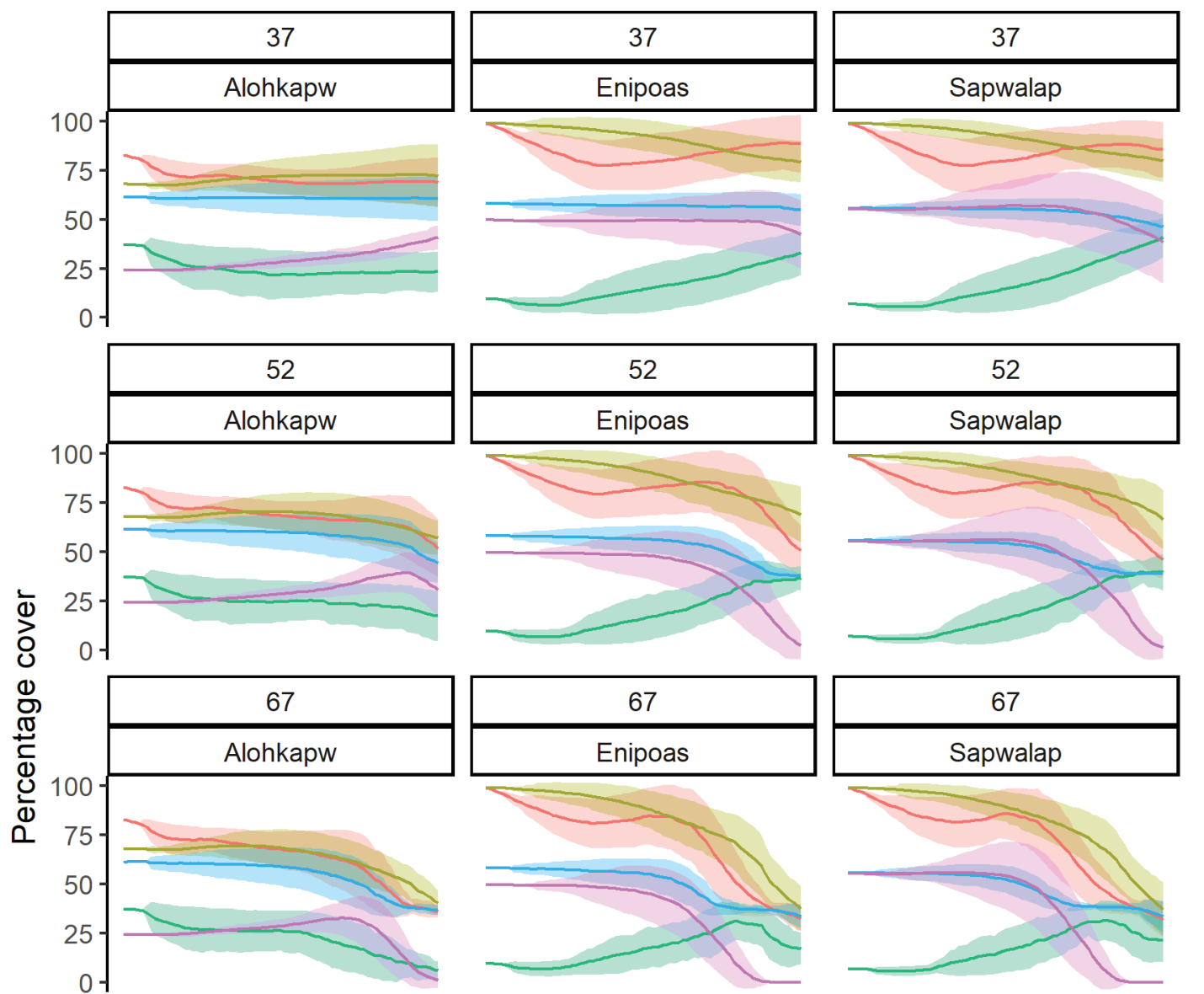

Species
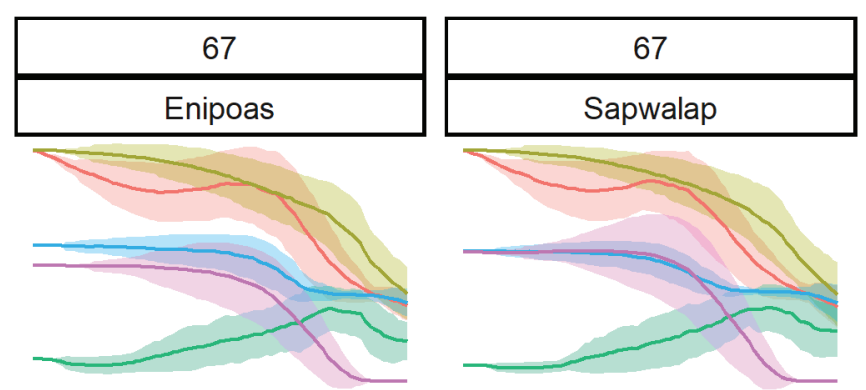

Bruguiera gymnorrhiza

Rhizophora apiculata Rhizophora stylosa Sonneratia alba Xylocarpus granatum
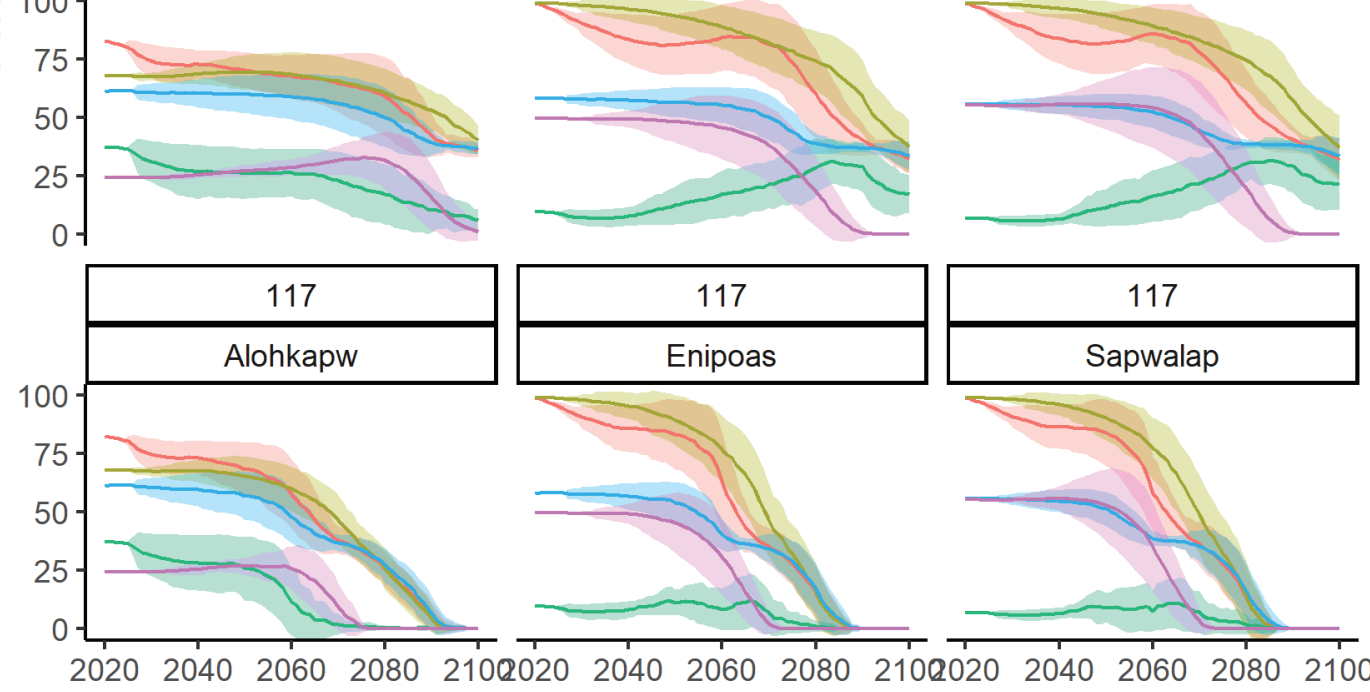

Year

Figure 13. Percentage ( \pm standard deviation) of the Alohkapw, Enipoas, and Sapwalap study areas on Pohnpei, Federated States of Micronesia, covered by each mangrove species projected to have more than 15-percent cover under low $(37 \mathrm{~cm})$, moderate $(52 \mathrm{~cm})$, high $(67 \mathrm{~cm})$, and extreme $(117 \mathrm{~cm})$ sea-level rise scenarios from 2020 to 2100. 


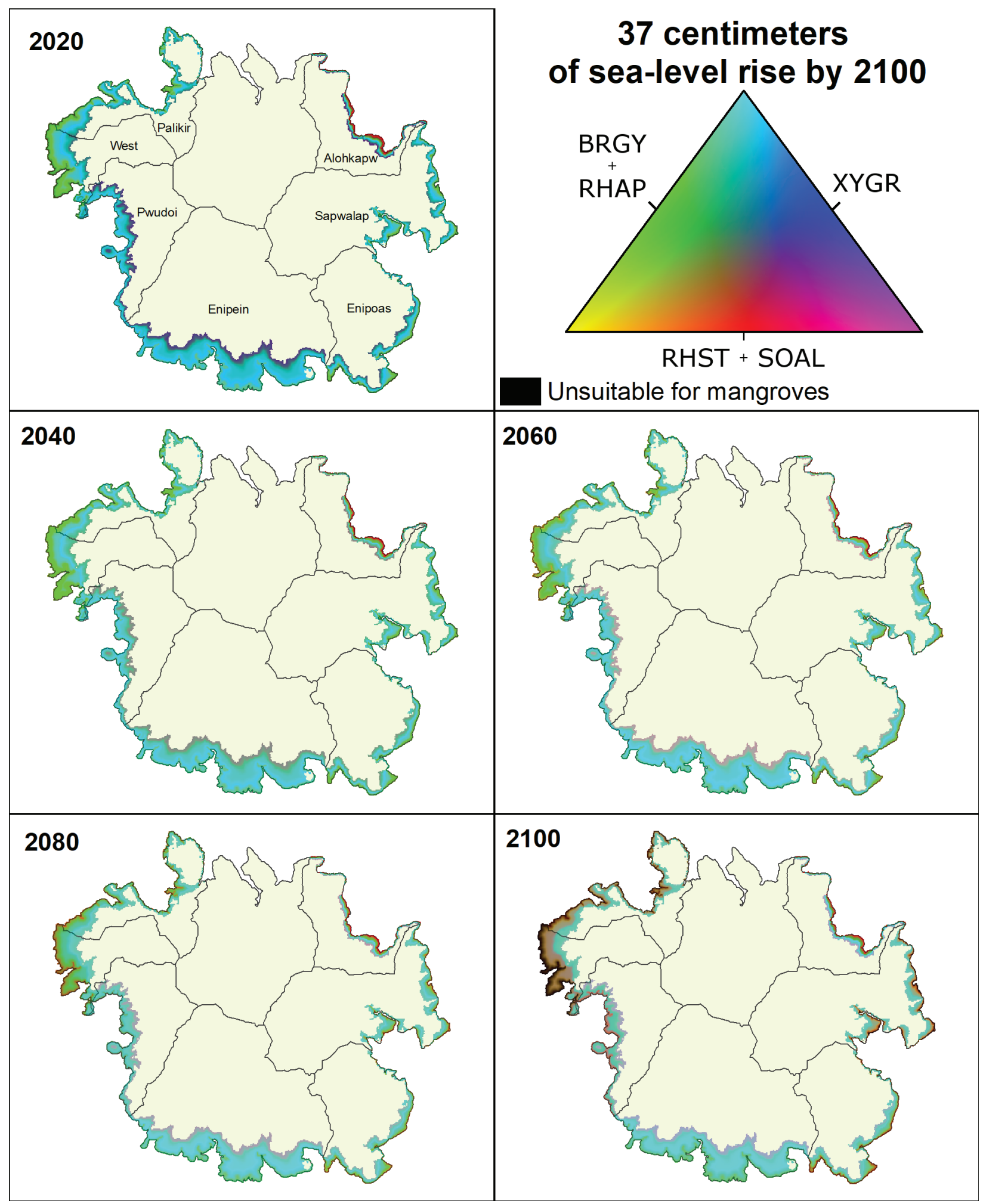

Figure 14. Mangrove community composition across Pohnpei, Federated States of Micronesia, under 2020 conditions and $37 \mathrm{~cm}$ of sea-level rise by 2100 in 20 -year intervals. 


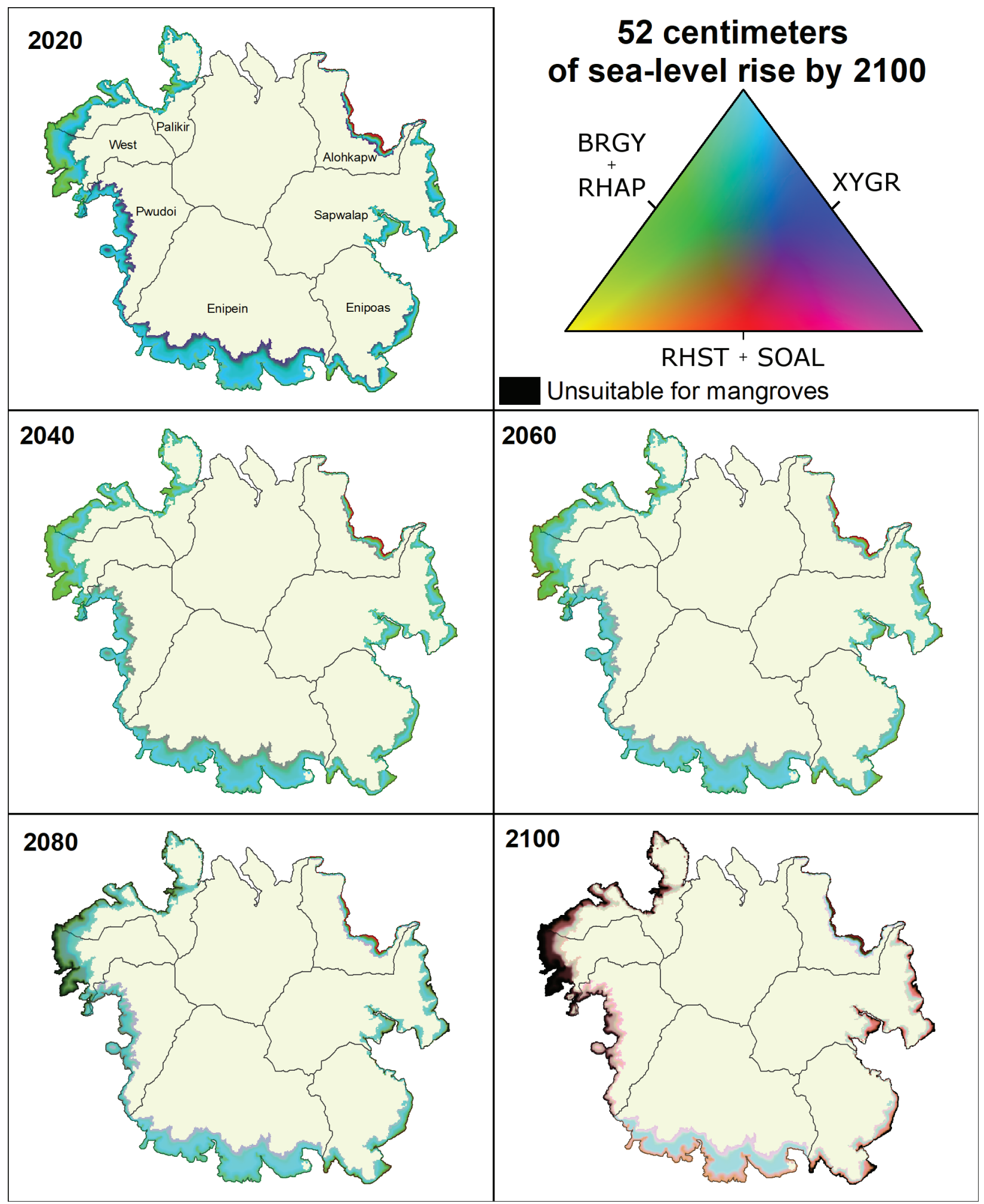

Figure 15. Mangrove community composition across Pohnpei, Federated States of Micronesia, under 2020 conditions and $52 \mathrm{~cm}$ of sea-level rise by 2100 in 20 -year intervals. 


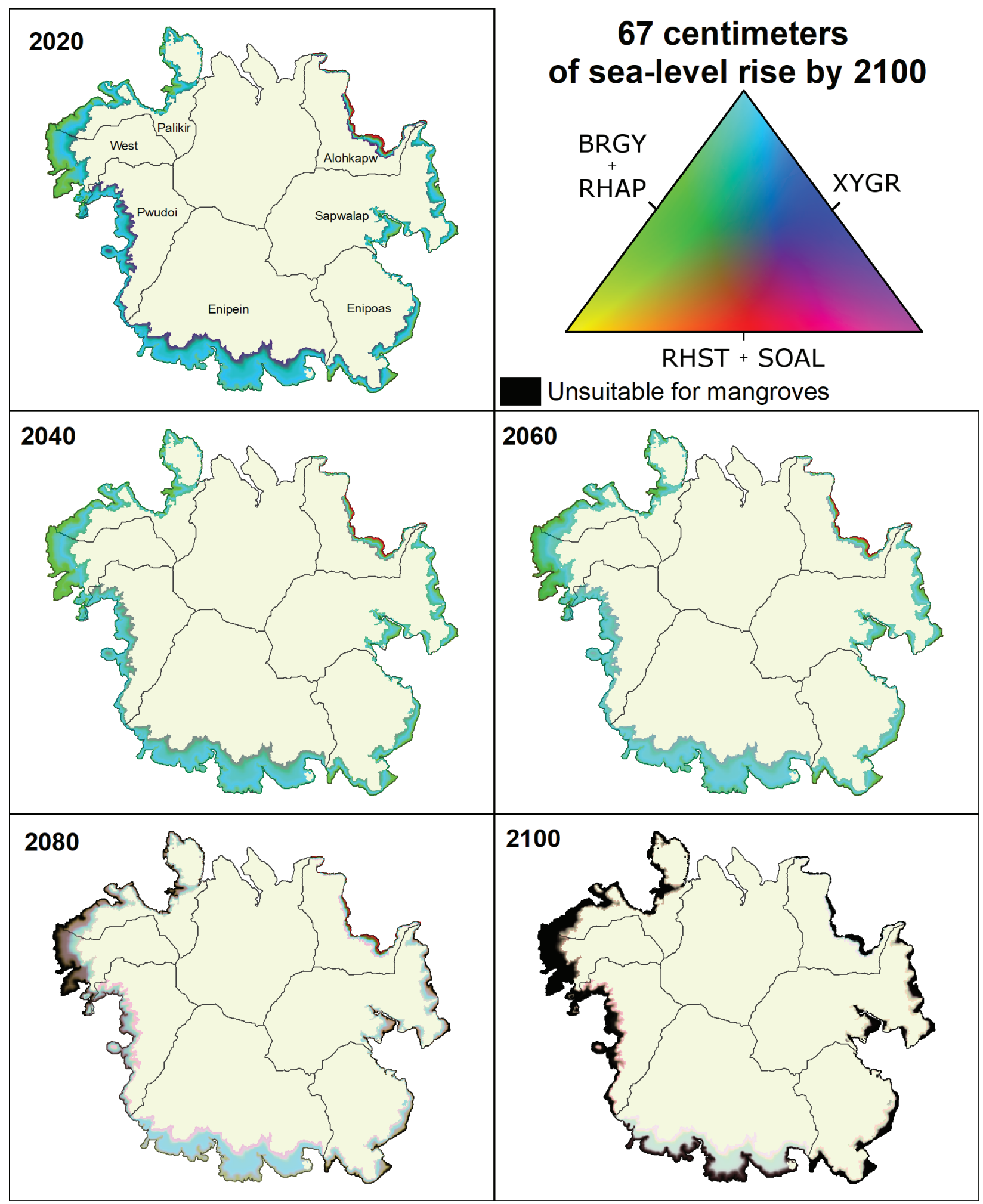

Figure 16. Mangrove community composition across Pohnpei, Federated States of Micronesia, under 2020 conditions and $67 \mathrm{~cm}$ of sea-level rise by 2100 in 20 -year intervals. 


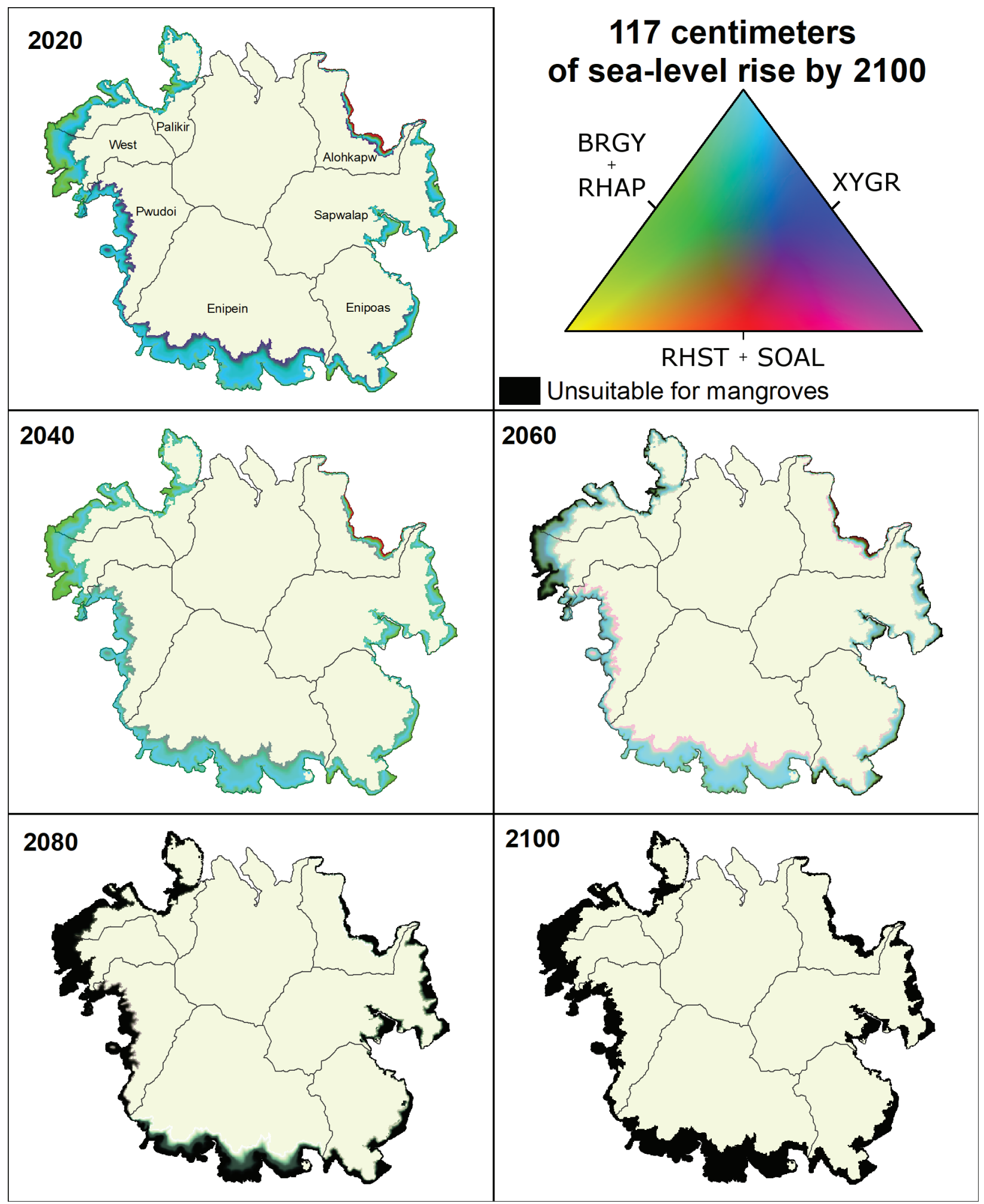

Figure 17. Mangrove community composition across Pohnpei, Federated States of Micronesia, under 2020 conditions and $117 \mathrm{~cm}$ of sea-level rise by 2100 in 20 -year intervals. 


\section{Discussion}

Our modeling results projected that mangroves around Pohnpei are likely to be resilient to low and moderate sea-level rise rates (fig. 11), with limited changes in community composition expected during the first 30 years of the 80 -year simulation (figs. 12, 13). The projected changes in mangrove community composition are consistent with a decrease in high elevation mangrove forest ( $X$. granatum) and a subsequent increase in low elevation forest (R. stylosa and S. alba). Our model domain did not include any adjacent upland areas that may transition to mangroves by migration. Pohnpei has steep slopes that are characteristic of its volcanic history; therefore, the potential area for upland transgression is likely quite limited. The absence of high-quality elevation data around the island makes it difficult to generate accurate projections of transgression, however. Mangroves may move inland in limited areas along specific rivers where elevation changes are more gradual.

Enipein, Sapwalap, Enipoas, and Alohkapw were the most resilient sites to sea-level rise and maintained their elevations and forest composition the longest in our model results (figs. 10-13). Alohkapw, Enipoas, and Sapwalap had relatively high elevations within the tidal frame, which increased their resilience, whereas community composition changes at Enipein maintained cover (fig. 12). The sites at Alohkapw and Sapwalap are also near large rivers and had higher mineral sediment accumulation rates (accretion) than the other sites (table 4), which contributed to their projected resilience. Forest clearing and other human activities in the watersheds of both sites may be responsible for the elevated rates of sediment deposition; it is also possible that these sites are naturally more resilient because they are near large rivers and natural sediment addition to the nearshore. Additional analysis of the dated soil-core intervals could help determine whether accretion rates at these sites have increased in the last 30 years in relation to human activities in the watershed rather than natural processes.

The most vulnerable region, West, is on the leeward side of the island, where the largest continuous area of mangrove forest grows. Compared with most other regions, this area had relatively low initial elevation (fig. 10) and low accretion rates, which translated to greater vulnerability in the future. Enipein is also on the leeward side of the island, but the model showed resilience under the $67 \mathrm{~cm}$ sea-level rise scenario. The elevation leveling surveys at Enipein and Palikir did not extend the full width of the mangroves, and no elevation data were available for West, making the initial DEM at these sites more uncertain compared to the other sites. Considering the projected high vulnerability and low measured accretion rates at some sites on the leeward side of the island, additional measurement and monitoring of mangrove elevations (for example, continued monitoring of new rod SETs installed in 2019 that were established with vertical elevation control) and water levels could provide valuable data.
Climate adaptation and planning may be important on Pohnpei given the uncertainty of future climate projections, greenhouse gas emissions, and complex ocean-ecological processes. This modeling can be used to reduce uncertainties in future mangrove forest change under sea-level rise scenarios, but continued monitoring and reassessments of the forest health over time would further inform planning. Also, our findings indicate that the present, relatively undisturbed state of the mangrove forests and the surrounding landscape is an important factor in their ability to keep pace with sea-level rise. Changes in environmental conditions (for example, less freshwater delivery or changes to the sediment regime) could alter the rates of organic or mineral accumulation, resulting in reduced vertical accretion and greater vulnerability to rising seas. Keeping intact riverine outputs to the estuary can maintain mangrove forest function and build resilience. Upslope mangrove forest migration is also an important process to consider facilitating into the future.

\section{Modeling Assumptions and Information Needs}

As with any model, we were required to make several simplifying assumptions and omit important processes because of a lack of local information. For this effort, we focused on the above and belowground processes that control elevation and mangrove response to changes in flooding. Salinity can be a dominant driver of community composition and productivity that we chose to omit owing to a lack of field data and specific knowledge of species responses. Similarly, the macronutrients nitrogen and phosphorus are known to play an important role in limiting mangrove growth in the Caribbean (Castañeda-Moya and others, 2013); however, we left nutrients out of our model to reduce model complexity and because we lacked calibration data. To some degree, the effects of salinity and nutrients are both captured in the elevation distributions for each species, and at a regional scale, by basal area distributions derived from forest inventory plots.

By calibrating the model with soil-core accumulation rates, we are assuming that the relationships between basal area and rates of productivity and decomposition over the last 75 years are representative of future conditions. Human development and climate change could both cause changes in the environment that affect mangrove productivity, however. For example, changes in freshwater delivery or sediment loading could have a strong effect on the health and resilience of Pohnpei mangroves. Additional scenarios of changes in sedimentation or productivity could be explored to understand the sensitivity of the projections to these assumptions. Furthermore, data that identify the source of the sediment in mangrove forests across each region are needed to understand what is ultimately driving relative resilience. For example, discharge and suspended sediment monitoring of major rivers would provide valuable information about variability of sediment inputs into mangrove forests. 
One of the greatest sources of uncertainty in our projections of future mangrove area is related to elevation. Without a continuous DEM of the mangrove forest, we chose to spatially extrapolate the elevation leveling transects and made broad assumptions about the slope of the forest at each site. Like similar models of wetland soils (for example, WARMER, Swanson and others, 2014), the projections are sensitive to initial elevation and the results should be interpreted with this uncertainty in mind. Additionally, there was no information about nearshore bathymetry, so our model domain only includes the mangrove extent as of 2019. It is likely that mangroves could prograde into adjacent reef habitats in some areas; however, this process is not considered in the model.

Additionally, the site-specific mean sea-level datum elevations were highly uncertain. Comparisons of short-term water-level data at two locations to the long-term water-level gage at the airport indicated there are differences in MSL around the island, which we attributed to prevailing winds and currents. Given the larger area of mangroves on the leeward southwest side of the island, it is probable there are differences in MSL or wave energy that affect mangrove establishment. Water-level monitoring around the island could ascertain the temporal and spatial nature of these differences and improve projections of mangrove sea-level rise vulnerability.

\section{Conclusions}

We developed a new, generalizable numerical modeling framework for assessing relative vulnerability of mangrove forests to accelerating sea-level rise. Through extensive calibration using empirical datasets, both new and sourced from the literature, we developed future projections of mangrove community composition and elevation in response to sea-level rise around Pohnpei, Federated States of Micronesia. Mangroves were projected to be resilient to low and moderate rates of sea-level rise; however, extensive loss of suitable mangrove habitat could result if the high or extreme sea-level rate scenario is realized. Variation in accretion rates and initial elevation around the island led to a range in projected vulnerability; mangroves on the leeward side of the island generally were the most at-risk to high rates of sea-level rise. Because of the lack of an accurate digital elevation model (DEM) in the mangroves and insufficient water-level monitoring, the long-term vulnerability of mangroves on Pohnpei remains uncertain.

Model output is available at

https://doi.org/10.5066/P96R8MZQ.

\section{References Cited}

Appleby, P.G., and Oldfield, F., 1978, The calculation of lead-210 dates assuming a constant rate of supply of unsupported $210 \mathrm{~Pb}$ to the sediment: Catena, v. 5 , no. 1 , p. 1-8, https://doi.org/10.1016/S0341-8162(78)80002-2.

Asaeda, T., and Kalibbala, M., 2009, Modelling growth and primary production of the marine mangrove (Rhizophora apiculata BL) - A dynamic approach: Journal of Experimental Marine Biology and Ecology, v. 371, no. 2, p. 103-111, https://doi.org/10.1016/j.jembe.2009.01.009.

Berger, U., and Hildenbrandt, H., 2000, A new approach to spatially explicit modelling of forest dynamics-Spacing, ageing and neighbourhood competition of mangrove trees: Ecological Modelling, v. 132, no. 3, p. 287-302, https://doi.org/10.1016/S0304-3800(00)00298-2.

Caldwell, P.C., Merrifield, M.A., and Thompson, P.R., 2015, Sea level measured by tide gauges from global oceans - The Joint Archive for Sea Level (JASL) since 1846-(NCEI Accession 0019568), Version 5.5: NOAA National Centers for Environmental Information, Dataset, http://doi.org/10.7289/V5V40S7W.

Castañeda-Moya, E., Twilley, R.R., and Rivera-Monroy, V.H., 2013, Allocation of biomass and net primary productivity of mangrove forests along environmental gradients in the Florida Coastal Everglades, USA: Forest Ecology and Management, v. 307, p. 226-241, https://doi.org/10.1016/j.foreco.2013.07.011.

Chen, R., and Twilley, R.R., 1998, A gap dynamic model of mangrove forest development along gradients of soil salinity and nutrient resources: Journal of Ecology, v. 86, no. 1, p. 37-51, https://doi.org/10.1046/j.1365-2745.1998.00233.x.

Chen, R., and Twilley, R.R., 1999, A simulation model of organic matter and nutrient accumulation in Mangrove wetland soils: Biogeochemistry, v. 44, no. 1, p. 93-118, https://doi.org/10.1007/BF00993000.

Church, J.A., Clark, P.U., Cazenave, A., Gregory, J.M., Jevrejeva, S., Levermann, A., Merrifield, M.A., Milne, G.A., Nerem, R.S., Nunn, P.D., Payne, A.J., Pfeffer, W.T., Stammer, D., and Unnikrishnan, A.S., 2013, Sea level change, chap. 13 of Stocker, T.F., Qin, D., Plattner, K.D., Tignor, M., Allen, S.K., Boschung, J., Nauels, A., Xia, Y., Bex, V., and Midgley, P.M., eds., Climate change 2013 - The physical science basisContribution of working group I to the fifth assessment report of the Intergovernmental Panel on Climate Change: Cambridge, United Kingdom and New York, NY, USA, Cambridge University Press, p. 1137-1216. 
Cole, T.G., Ewel, K.C., and Devoe, N.N., 1999, Structure of mangrove trees and forests in Micronesia: Forest Ecology and Management, v. 117, no. 1-3, p. 95-109, https://doi.org/10.1016/S0378-1127(98)00474-5.

Cormier, N., Twilley, R.R., Ewel, K.C., and Krauss, K.W., 2015, Fine root productivity varies along nitrogen and phosphorus gradients in high-rainfall mangrove forests of Micronesia: Hydrobiologia, v. 750, no. 1, p. 69-87, https://oi.org/10.1007/s10750-015-2178-4.

Craft, C., Clough, J., Ehman, J., Joye, S., Park, R., Pennings, S., Guo, H., and Machmuller, M., 2009, Forecasting the effects of accelerated sea-level rise on tidal marsh ecosystem services: Frontiers in Ecology and the Environment, v. 7, no. 2, p. 73-78, https://doi.org/10.1890/070219.

Dahdouh-Guebas, F., and Jayatissa, L.P., 2009, A bibliometrical review on pre- and post-tsunami assumptions and facts about mangroves and other coastal vegetation as protective buffers: Ruhuna Journal of Science, v. 4, p. $28-50$, https://doi.org/10.4038/rjs.v4i0.58.

Danielsen, F., Sørensen, M.K., Olwig, M.F., Selvam, V., Parish, F., Burgess, N.D., Hiraishi, T., Karunagaran, V.M., Rasmussen, M.S., Hansen, L.B., Quarto, A., and Suryadiputra, N., 2005, The Asian tsunami-A protective role for coastal vegetation: Science, v. 310 , no. 5748 , p. 643 , https://doi.org/10.1126/science.1118387.

Devoe, N.N., and Cole, T.G., 1998, Growth and yield in mangrove forests of the Federated States of Micronesia: Forest Ecology and Management, v. 103, no. 1, p. 33-48, https://doi.org/10.1016/S0378-1127(97)00176-X.

Donato, D.C., Kauffman, J.B., Murdiyarso, D., Kurnianto, S., Stidham, M., and Kanninen, M., 2011, Mangroves among the most carbon-rich forests in the tropics: Nature Geoscience, v. 4, no. 5, p. 293-297, https://doi.org/10.1038/ngeo1123.

Fagherazzi, S., Kirwan, M.L., Mudd, S.M., Guntenspergen, G.R., Temmerman, S., D'Alpaos, A., van de Koppel, J., Rybczyk, J.M., Reyes, E., Craft, C., and Clough, J., 2012, Numerical models of salt marsh evolution-Ecological, geomorhpic, and climatic factors: Reviews of Geophysics, v. 50, no. 1, 28 p., https://doi.org/10.1029/2011RG000359.

Gleason, S.M., and Ewel, K.C., 2002, Organic matter dynamics on the forest floor of a Micronesian mangrove forest-An investigation of species composition shifts: Biotropica, v. 34, no. 2, p. 190-198, https://doi.org/10.1111/j.1744-7429.2002.tb00530.x.
Irwin, J.R., Gesch, D.B., Buffington, K.J., and Danielson, J.J., 2021, Pohnpei, Federated States of Micronesia Mangrove Elevation Survey Data: U.S. Geological Survey data release, https://doi.org/10.5066/P9DDZX32.

Jiang, J., DeAngelis, D.L., Smith, T.J., III, Teh, S.Y., and Koh, H.L., 2012, Spatial pattern formation of coastal vegetation in response to external gradients and positive feedbacks affecting soil porewater salinity - A model study: Landscape Ecology, v. 27, no. 1, p. 109-119, https://doi.org/10.1007/s10980-011-9689-9.

Kirwan, M.L., Guntenspergen, G.R., D’Alpaos, A., Morris, J.T., Mudd, S.M., and Temmerman, S., 2010, Limits on the adaptability of coastal marshes to rising sea level: Geophysical Research Letters, v. 37, no. 23, 5 p., https://doi.org/10.1029/2010GL045489.

Komiyama, A., Ong, J.E., and Poungparn, S., 2008, Allometry, biomass, and productivity of mangrove forests-A review: Aquatic Botany, v. 89, no. 2, p. 128-137, https://doi.org/10.1016/j.aquabot.2007.12.006.

Kopp, R.E., Horton, R.M., Little, C.M., Mitrovica, J.X., Oppenheimer, M., Rasmussen, D.J., Strauss, B.H., and Tebaldi, C., 2014, Probabilistic 21st and 22nd century sea-level projections at a global network of tide-gauge sites: Earth's Future, v. 2, no. 8, p. 383-406, https://doi.org/10.1002/2014EF000239.

Kramer-Walter, K.R., Bellingham, P.J., Millar, T.R., Smissen, R.D., Richardson, S.J., and Laughlin, D.C., 2016, Root traits are multidimensional-Specific root length is independent from root tissue density and the plant economic spectrum: Journal of Ecology, v. 104, no. 5, p. 1299-1310, https://doi.org/10.1111/1365-2745.12562.

Krauss, K.W., Cahoon, D.R., Allen, J.A., Ewel, K.C., Lynch, J.C., and Cormier, N., 2010, Surface elevation change and susceptibility of different mangrove zones to sea-level rise on Pacific high islands of Micronesia: Ecosystems (New York, N.Y.), v. 13, no. 1, p. 129-143, https://doi.org/10.1007/s10021-009-9307-8.

Krauss, K.W., McKee, K.L., Lovelock, C.E., Cahoon, D.R., Saintilan, N., Reef, R., and Chen, L., 2014, How mangrove forests adjust to rising sea level: The New Phytologist, v. 202, no. 1, p. 19-34, https://doi.org/10.1111/nph.12605.

Lander, M.A., and Khosrowpanah, S., 2004, Rainfall climatology for Pohnpei Island, Federated States of Micronesia: Water and Environmental Research Institute of the Western Pacific Technical Report 103, 51 p. 
Langston, A.K., Durán Vinent, O., Herbert, E.R., and Kirwan, M.L., 2020, Modeling long-term salt marsh response to sea level rise in the sediment-deficient Plum Island Estuary, MA: Limnology and Oceanography, v. 65, no, 9, p. 2142-2157, https://doi.org/10.1002/lno.11444.

Lovelock, C.E., Cahoon, D.R., Friess, D.A., Guntenspergen, G.R., Krauss, K.W., Reef, R., Rogers, K., Saunders, M.L., Sidik, F., Swales, A., Saintilan, N., Thuyen, L.X., and Triet, T., 2015, The vulnerability of Indo-Pacific mangrove forests to sea-level rise: Nature, v. 526, no. 7574, p. 559-563, https://doi.org/10.1038/nature15538.

MacKenzie, R.A., Foulk, P.B., Klump, J.V., Weckerly, K., Purbospito, J., Murdiyarso, D., Donato, D.C., and Nam, V.N., 2016, Sedimentation and belowground carbon accumulation rates in mangrove forests that differ in diversity and land use - A tale of two mangroves: Wetlands Ecology and Management, v. 24, no. 2, p. 245-261, https://doi.org/10.1007/s11273-016-9481-3.

Morris, J.T., Sundareshwar, P.V., Nietch, C.T., Kjerfve, B., and Cahoon, D.R., 2002, Responses of coastal wetlands to rising sea level: Ecology, v. 83, no. 10, p. 2869-2877, https://doi.org/10.1890/00129658(2002)083[2869:ROCWTR]2.0.CO;2.

Morris, J.T., Barber, D.C., Callaway, J.C., Chambers, R., Hagen, S.C., Hopkinson, C.S., Johnson, B.J., Megonigal, P., Neubauer, S.C., Troxler, T., and Wigand, C., 2016, Contributions of organic and inorganic matter to sediment volume and accretion in tidal wetlands at steady state: Earth's Future, v. 4, no. 4, p. 110-121, https://doi.org/10.1002/2015EF000334.

Naylor, R.L., Bonine, K.M., Ewel, K.C., and Waguk, E., 2002, Migration, markets, and mangrove resource use on Kosrae, Federated States of Micronesia: Ambio, v. 31, no. 4, p. 340-350, https://doi.org/10.1579/0044-7447-31.4.340.
Ono, K., Hiradate, S., Morita, S., Hiraide, M., Hirata, Y., Fujimoto, K., Tabuchi, R., and Lihpai, S., 2015, Assessing the carbon compositions and sources of mangrove peat in a tropical mangrove forest on Pohnpei Island, Federated States of Micronesia: Geoderma, v. 245-246, p. 11-20, https://doi.org/10.1016/j.geoderma.2015.01.008.

Peneva-Reed, E., and Zhu, Z., 2019, Aboveground biomass data collected in 2016-17 from Pohnpei, Federated States of Micronesia: U.S. Geological Survey data release, https://doi.org/10.5066/P9JAE5JC.

Rybczyk, J.M., Callaway, J.C., and Day, J.W., Jr., 1998, A relative elevation model for a subsiding coastal forested wetland receiving wastewater effluent: Ecological Modelling, v. 112, no. 1, p. 23-44, https://doi.org/10.1016/S0304-3800(98)00125-2.

Saintilan, N., Khan, N.S., Ashe, E., Kelleway, J.J., Rogers, K., Woodroffe, C.D., and Horton, B.P., 2020, Thresholds of mangrove survival under rapid sea level rise: Science, v. 368, no. 6495, p. 1118-1121, https://doi.org/10.1126/science.aba2656.

Swanson, K.M., Drexler, J.Z., Schoellhamer, D.H., Thorne, K.M., Casazza, M.L., Overton, C.T., Callaway, J.C., and Takekawa, J.Y., 2014, Wetland accretion rate model of ecosystem resilience (WARMER) and its application to habitat sustainability for endangered species in the San Francisco Estuary: Estuaries and Coasts, v. 37, no. 2, p. 476-492, https://doi.org/10.1007/s12237-013-9694-0.

van Maanen, B., Coco, G., and Bryan, K.R., 2015, On the ecogeomorphological feedbacks that control tidal channel network evolution in a sandy mangrove setting: Proceedings of the Royal Society A-Mathematical, Physical and Engineering Science, v. 471, no. 2180, 24 p., https://doi.org/10.1098/rspa.2015.0115. 


\section{Appendix 1. Model equations for Mangrove Species' Response to Sea-Level Rise, Pohnpei, Federated States of Micronesia}

The model tracks changes in elevation, relative to mean sea level, through time as soil develops through processes of mineral and organic deposition, decomposition, and soil consolidation:

$$
\frac{\mathrm{dz}}{\mathrm{dt}}=\frac{Q_{o}\left(z, P_{i}\right)+Q_{c}(z)+V\left(z, P_{i}\right)}{1 \mathrm{~cm} m^{2}}-S(t)
$$

where

$$
\begin{array}{cl}
\mathrm{d} & \text { is change; } \\
\mathrm{t} & \text { is time (years); } \\
\mathrm{Z} & \text { is elevation relative to mean sea level }(\mathrm{cm}) ; \\
\mathrm{P} & \text { is the total fractional basal area for } \\
\mathrm{i} & \text { each species; } \\
\mathrm{Q}_{\mathrm{o}} & \text { is the net volume of organic matter input } \\
\text { from root and litter production, less } \\
\text { decomposition, for all species }\left(\mathrm{cm}^{3}\right) ; \\
\mathrm{Q}_{\mathrm{c}} \quad \text { is the volume of inorganic mineral } \\
\mathrm{V} \quad \text { is the volume of living and dead roots } \\
\text { ( } \left.\mathrm{cm}^{3}\right) \text {; and } \\
\mathrm{S} \quad \text { is the annual change in mean sea level }(\mathrm{cm}) .
\end{array}
$$

A change in fractional basal area by species was modeled as a function of elevation and carrying capacity:

$$
\frac{d P_{i}}{d t}=P_{i} r 1_{i}\left[1-\frac{P_{i}}{\left(k-P_{j}\right) E(z, i)}\right]
$$

where

$$
\begin{aligned}
P_{i} & \text { is fractional basal area for each species; } \\
P_{j} & \text { is the total fractional basal area excluding } \\
r 1_{i} & \text { is the maximum growth rate for species } i \\
& \text { (fractional basal area/year); } \\
k & \text { is the carrying capacity of the site, defined as } \\
& \text { fractional basal area; and }
\end{aligned}
$$

All cover lost at the beginning of the time step is transferred to the standing dead pool:

$$
\begin{gathered}
\frac{d D_{i}}{d t}=\left(\frac{D_{i}+d P_{i}}{d t}\right) d f \text { if } \frac{d P_{i}}{d t}<0 \\
\frac{d D_{i}}{d t}=D_{i} d f \text { if } \frac{d P_{i}}{d t}>0
\end{gathered}
$$

where

$D_{i} \quad$ is the standing-dead pool for species $i$ (fractional basal area); and

$d_{f} \quad$ is the standing-dead fall rate that transfers standing dead cover to the fallen dead pool (fractional basal area/year).

Species growth rate, in terms of fractional basal area, was converted to a relative rate that, such that:

$$
r 1_{i}=r_{a}\left(\frac{r_{i}}{D B H_{i}}-\frac{\sum 1 \frac{r_{i}}{D B H_{i}}}{N}\right)
$$

where

$\mathrm{r}_{\mathrm{i}} \quad$ is the maximum growth rate for species $\mathrm{i}$ (fractional basal area/year);

$r_{a} \quad$ is the absolute growth rate (fractional basal area/year);

$r_{i} \quad$ is the growth rate for species $\mathrm{i}$ (meters/year);

$\mathrm{DBH}_{\mathrm{i}}$ is the mean diameter at breast height (meters) of species $\mathrm{i}$; and

$\mathrm{N}$ is the total number of species in the model.

Leaf and wood litter (grams) is separated into the surface pools of labile and refractory organic matter as follows:

$$
\begin{gathered}
O_{r_{n}}=\text { litte }_{\text {leaf }} l_{r}+\text { litte } r_{\text {wood }}\left(1-f_{c} 2\right) \\
O_{l_{n}}=\operatorname{litter}_{\text {leaf }}\left(1-l_{r}\right)+\text { litte } r_{\text {wood }}\left(f_{c} 2\right)
\end{gathered}
$$

where

$$
\begin{array}{cl}
n & \text { is the cohort (and here equal to one for the } \\
O_{l} & \text { is the labile organic matter pool; } \\
O_{r} & \text { is the refractory organic matter pool; } \\
l_{r} & \text { is the refractory proportion for leaf litter; and } \\
f_{c} 2 & \text { is the labile proportion for large roots } \\
& \text { and wood. }
\end{array}
$$


Leaf and wood litter comes from the aboveground living and fallen dead pools, such that wood (for example, branches) is assumed to fall at half of the leaf rate, and the export rate is assumed to be proportional to the annual inundation time percent:

$$
\begin{gathered}
\text { Litter }_{\text {leaf }}=l_{d} l_{e} \sum B_{\text {living }} \\
\text { Litter }_{\text {wood }}=l_{e}\left(\frac{l_{d}}{2} \sum B_{\text {living }}+\sum B_{\text {dead }}\right)
\end{gathered}
$$

where

$$
\begin{aligned}
& B_{\text {living }} \begin{array}{c}
\text { is the aboveground biomass of living } \\
\text { mangroves }(\mathrm{g}) ;
\end{array} \\
& B_{\text {dead }} \begin{array}{l}
\text { is the biomass of fallen, dead mangroves }(\mathrm{g}) ; \\
l_{d}
\end{array} \\
& \begin{array}{c}
\text { is the proportion of biomass deposited as } \\
\text { leaves, and }
\end{array} \\
& l_{e} \begin{array}{c}
\text { is the proportion of net export out of } \\
\text { the system. }
\end{array}
\end{aligned}
$$

Root mass was passed to the soil cohort module for calculation of total cohort volume and distributed downcore according to an exponential decay function:

$$
K(z)_{n}=r_{2} h_{n} K(z)^{-r_{2}\left(h+h_{n}\right)} \text { and } n>1
$$

where

$$
\begin{aligned}
K & \text { is living }\left(\mathrm{B}_{\mathrm{b}}\right) \text { and dead root }\left(\mathrm{B}_{\mathrm{d}}\right) \text { biomass }(\mathrm{g}) ; \\
n & \text { is the cohort; } \\
r 2 & \text { is a coefficient that controls the } \\
& \quad \text { exponential decay; } \\
h & \text { is the cumulative depth to cohort } n(\mathrm{~cm}) ; \text { and } \\
h_{n} & \text { is the volume of cohort } n\left(\mathrm{~cm}^{3}\right) .
\end{aligned}
$$

For structural roots, $r 2$ was multiplied by 1.5 to represent the pneumatophore root structures near the surface. The rates of organic matter decomposition $\left(\mathrm{g} / \mathrm{cm}^{2} /\right.$ year) from the labile $\left(\operatorname{Loss}_{\mathrm{L}}\right)$ and refractory $\left(\operatorname{Loss}_{\mathrm{R}}\right)$ pools were expressed as a function of percent time inundated and a decay constant for each type of organic matter:

$$
\begin{gathered}
\operatorname{Loss}_{L}=k_{l x} e^{-F(z-h) k_{l}} \\
\operatorname{Loss}_{R}=\frac{k_{l x}}{k_{r e}} e^{-F(z-h) k_{l}}
\end{gathered}
$$

where

$$
\begin{gathered}
k_{l x} \quad \begin{array}{c}
\text { is the maximum loss fraction for labile } \\
\text { organic matter; }
\end{array} \\
F \quad \text { is the flooding duration for the elevation of } \\
\text { the cohort (annual percent time); } \\
k_{l} \quad \text { is the coefficient that controls the effect of } \\
\quad \text { flooding on decomposition; and }
\end{gathered}
$$
$k_{r c} \quad$ is the factor by which the decomposition rate for refractory organic matter is reduced relative to the labile rate.

Living root turnover was distributed into three litter pools by root size class (fig. 3). Each size class had unique turnover rates informed by calibration (structural) and the literature (large and fine; Cormier and others, 2015).

$$
R_{s n}=k_{t} B_{b_{n}} y_{1}
$$

$$
\begin{gathered}
R_{l n}=k_{m} B_{b_{n}}\left(1-y_{1}\right)\left(1-y_{2}\right) \\
R_{f n}=k_{r} B_{b_{n}}\left(1-y_{1}\right) y_{2}
\end{gathered}
$$

where

$$
\begin{aligned}
\mathrm{n} & \text { is the cohort; } \\
R_{s} & \text { is structural root litter pool }(\mathrm{g}) ; \\
R_{l} & \text { is large root litter pool }(\mathrm{g}) ; \\
R_{f} & \text { is fine root litter pool }(\mathrm{g}) ; \\
B_{b} & \text { is the total living root biomass of cohort } n(\mathrm{~g}) ; \\
k_{t} & \text { is the annual turnover rate for structural roots; } \\
k_{m} & \text { is the annual turnover rate for large roots; } \\
k_{r} & \text { is the annual turnover rate for fine roots; } \\
y_{1} & \text { is the fraction of structural root biomass; and } \\
y_{2} & \text { is the fraction of fine roots from the remaining } \\
& \text { root biomass pool. }
\end{aligned}
$$

Dead roots are composed of labile and refractory pools that lose mass at different rates and according to logarithmic decay based on the age of the dead material:

$$
\begin{gathered}
B_{d l_{n}}=B_{d_{n}} f c 2\left(\frac{1}{1+e^{-\left(l_{n}-a\right) d_{l}}}\right) \\
B_{d r_{n}}=B_{d_{n}}(1-f c 2)\left(\frac{1}{\left.1+e^{-\left(r_{n}-a\right) d_{r}}\right)}\right) \\
B_{d_{n(t+1)}}=B_{d_{n}(t)}-B_{d l_{n(t)}}-B_{d r_{n(t)}}
\end{gathered}
$$

where

$\begin{aligned} t & \text { is timestep (1-year interval); } \\ B_{d} & \text { are dead roots (g); } \\ B_{d l} & \text { is the dead root labile pool (g); } \\ B_{d r} & \text { is the dead root refractory pool }(\mathrm{g}) ; \\ f_{c} 2 & \text { is the large root labile fraction; } \\ a & \text { is the age of the dead root (years); } \\ l_{h} & \text { is the half-life age of labile material (years); } \\ r_{h} & \text { is the half-life age of refractory } \\ & \text { material (years); } \\ d_{l} & \text { is the loss rate for labile material; and } \\ d_{r} & \text { is the loss rate for refractory material. }\end{aligned}$




$$
B D_{n}=\frac{1}{\frac{O M+\log \left(\sum_{n}^{1} M_{a}\right) k_{3}}{k_{1}}+\frac{1-O M}{k_{2}}}
$$

where

$$
\begin{array}{cl}
B D & \text { is bulk density }\left(\mathrm{g} / \mathrm{cm}^{3}\right) \text {; and } \\
O M & \text { is the percent organic matter }(0-100) ; \\
\mathrm{M}_{\mathrm{a}} & \text { is the sum of the organic and mineral matter } \\
& \text { in cohort } \mathrm{n}(\mathrm{g}) ; \\
\mathrm{k}_{1} & \text { is the density of pure organic } \\
& \text { sediments }\left(\mathrm{g} / \mathrm{cm}^{3}\right) ; \\
\mathrm{k}_{2} & \text { is the density of pure mineral sediments } \\
& \quad\left(\mathrm{gcm}^{3}\right) \text {; and } \\
\mathrm{k}_{3} \quad \text { is a coefficient that describes the rate of } \\
\quad \text { increase in BD per the mass above. }
\end{array}
$$

Percent organic matter of the soil cohort was used with the mineral content to calculate bulk density, which in combination with the living and dead roots, was used to calculate cohort volume:

$$
V_{n}=\frac{O_{r_{n}}+O_{l_{n}}+M_{n}}{B D}+\frac{R_{f n}}{d_{f}}+\frac{R_{l n}}{d_{l}}+\frac{R_{s n}}{d_{s n}}+\frac{\left(B_{b_{n}}-R_{f n}\right)}{d_{f}}+\frac{\left(B_{b_{n}}-R_{l n}\right)}{d_{l}}
$$

where

$$
d_{f} \quad \text { is the density of fine roots }\left(\mathrm{g} / \mathrm{cm}^{3}\right) \text {; }
$$

$$
\begin{aligned}
& \mathrm{d}_{1} \quad \text { is the density of large roots }\left(\mathrm{g} / \mathrm{cm}^{3}\right) \text {; and } \\
& \mathrm{d}_{\mathrm{sn}} \quad \begin{array}{l}
\text { is the species-specific density of structural } \\
\text { roots }\left(\mathrm{g} / \mathrm{cm}^{3}\right)
\end{array}
\end{aligned}
$$

Total soil depth (cm), $T$, is calculated as:

$$
T=\sum k V
$$

where

$$
\begin{gathered}
\mathrm{N} \quad \text { is the total number of cohorts } \\
M S L_{\text {logger }}=M S L_{\text {gage }}-\left(M H W_{\text {logger }}-M H W_{\text {gage }}\right) \\
W_{r}=\frac{D_{s}}{\frac{D_{s}+D_{u}}{W_{m}}}
\end{gathered}
$$

where

$\mathrm{W}_{\mathrm{r}} \quad$ is the relative width of the mangrove forest (m);

$D_{s} \quad$ is the distance from shore (m);

$D_{u} \quad$ is the distance from the upland mangrove forest edge $(\mathrm{m})$; and

$W_{m} \quad$ is the maximum width of the mangrove forest (maximum of $\mathrm{D}_{\mathrm{s}}+\mathrm{D}_{\mathrm{u}} ; \mathrm{m}$ ). 


\section{Appendix 2. Model Calibration of Mangrove Species' Response to Sea-Level Rise, Pohnpei, Federated States of Micronesia}
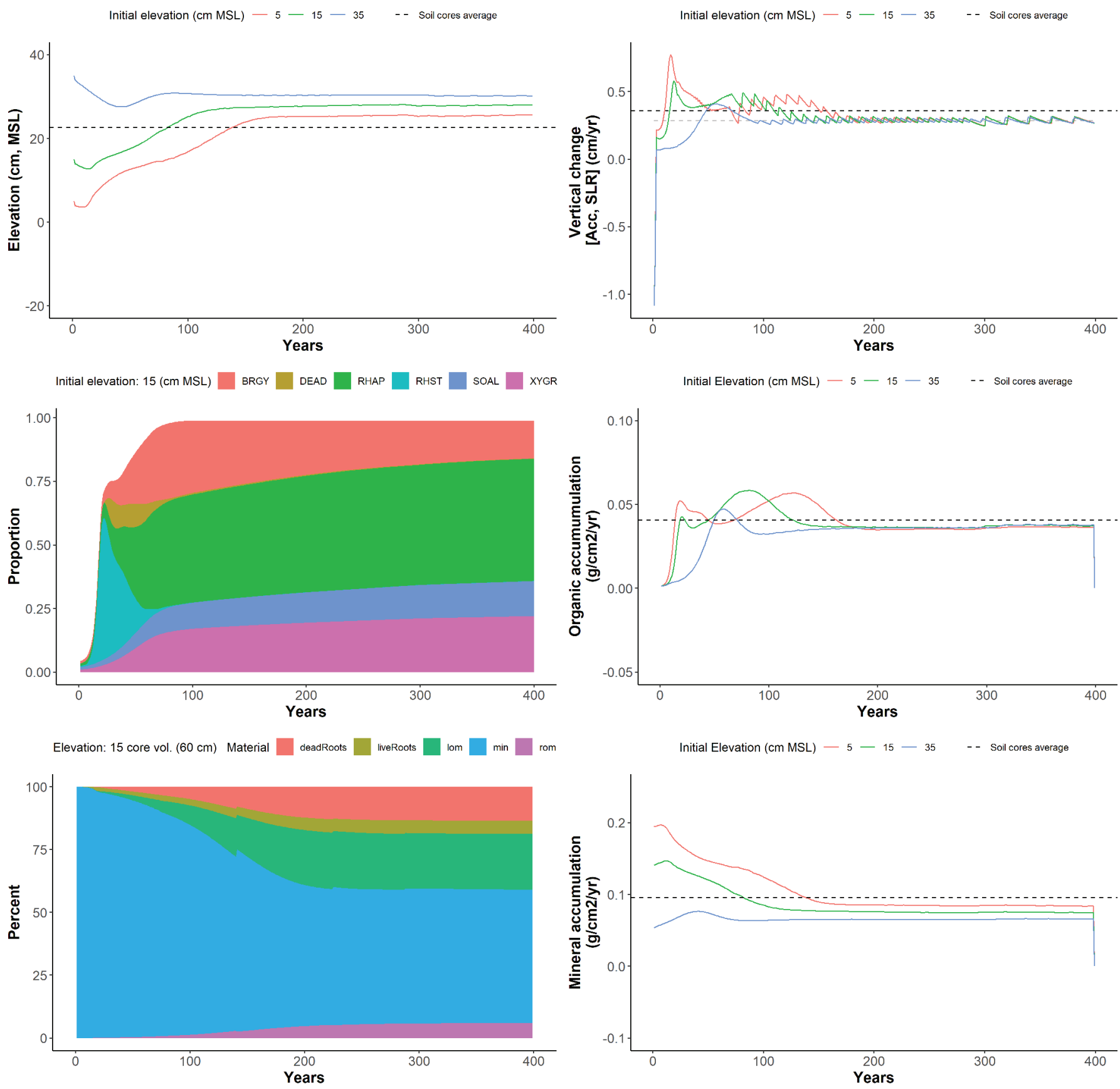

Figure 2.1. Calibration of elevation-related parameters using soil core-derived accretion and organic and mineral accumulation values at three initial model elevations, Alohkapw, Pohnpei, Federated States of Micronesia, using a 400-year spin-up period. 

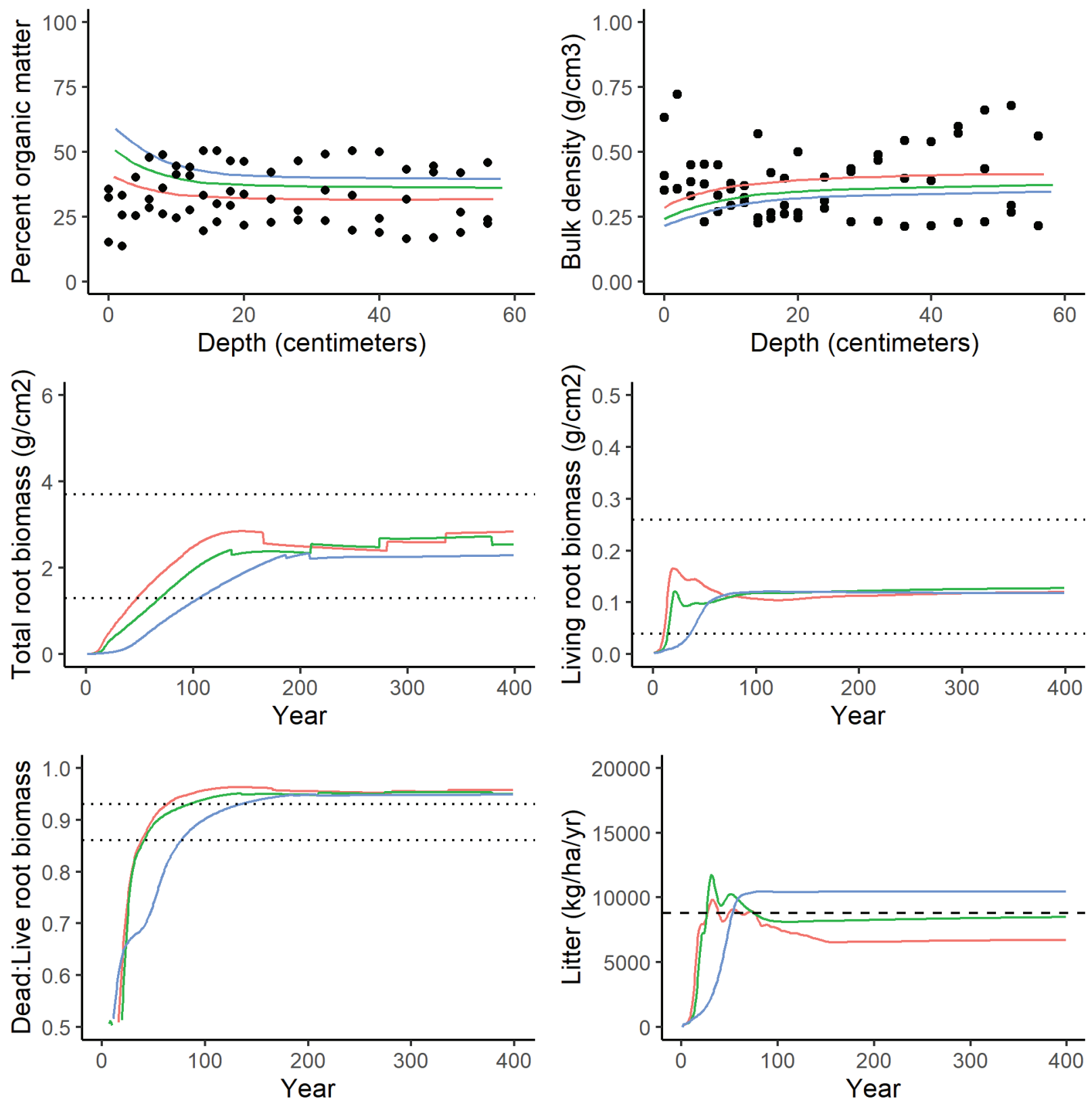

.... Published range - - Published mean

- Soil core data Elevation - $5-15-35$

Figure 2.2. Comparison of modeled soil and biomass characteristics with data from soil cores and the literature, Alohkapw, Pohnpei, Federated States of Micronesia, using three initial model elevations (centimeters, mean sea level) and a 400 -year calibration period. 

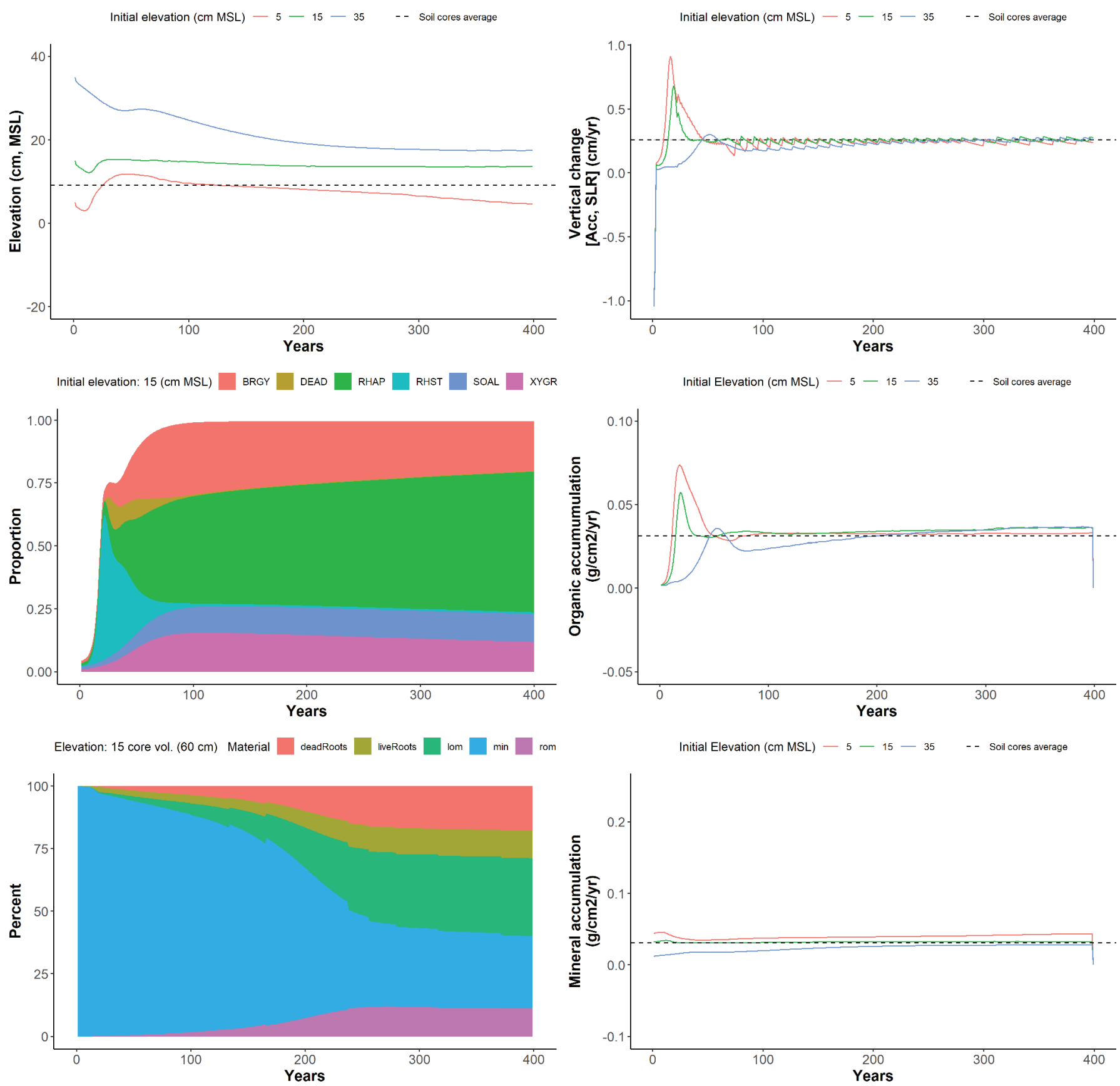

Figure 2.3. Calibration of elevation-related parameters using soil core-derived accretion and organic and mineral accumulation values at three initial model elevations, Enipein, Pohnpei, Federated States of Micronesia, using a 400-year spin-up period. 

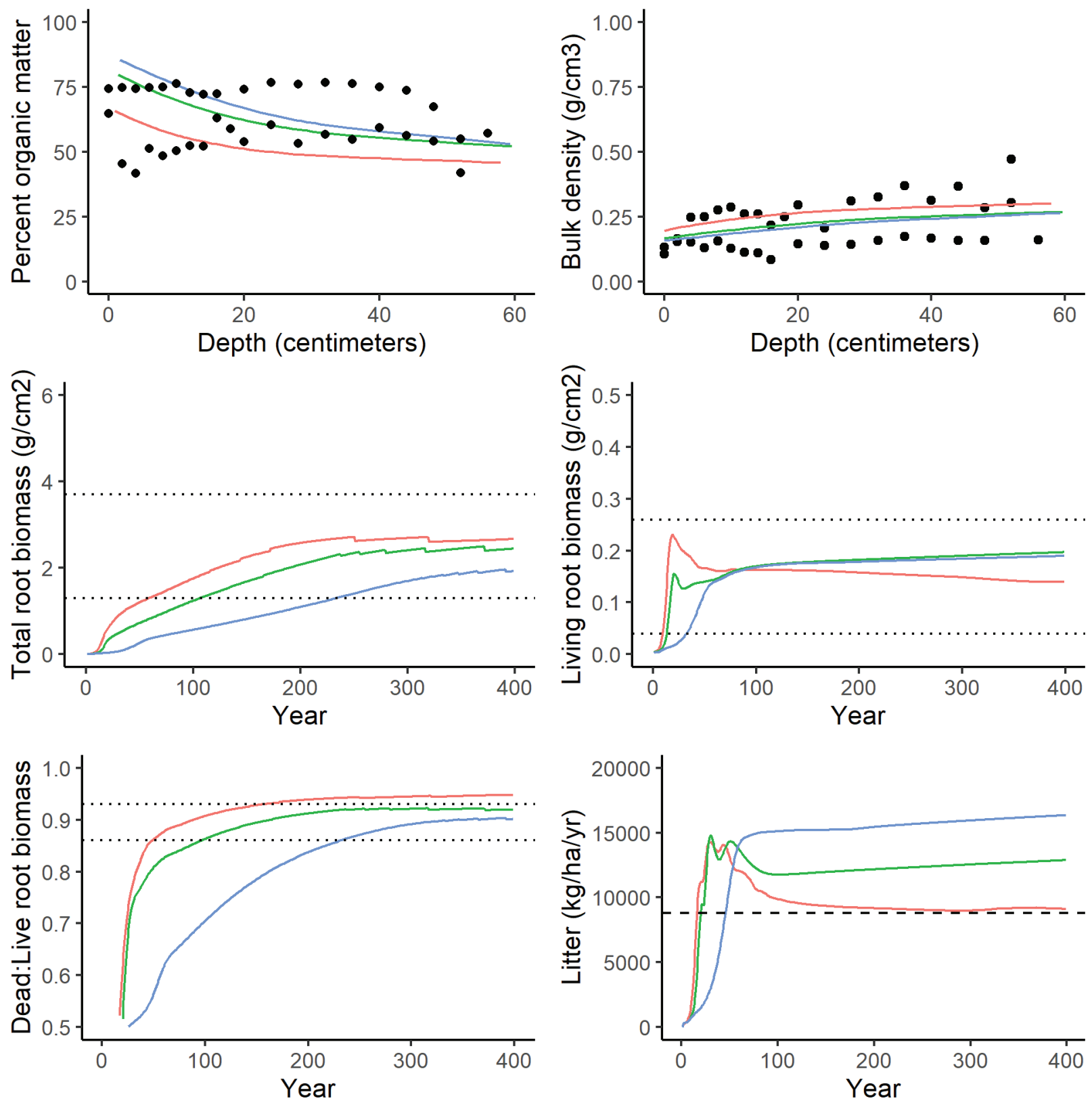

… Published range - - Published mean

- Soil core data Elevation - $5-15-35$

Figure 2.4. Comparison of modeled soil and biomass characteristics with data from soil cores and the literature, Enipein, Pohnei, Federated States of Micronesia, using three initial model elevations (centimeters, mean sea level) and a 400-year calibration period. 

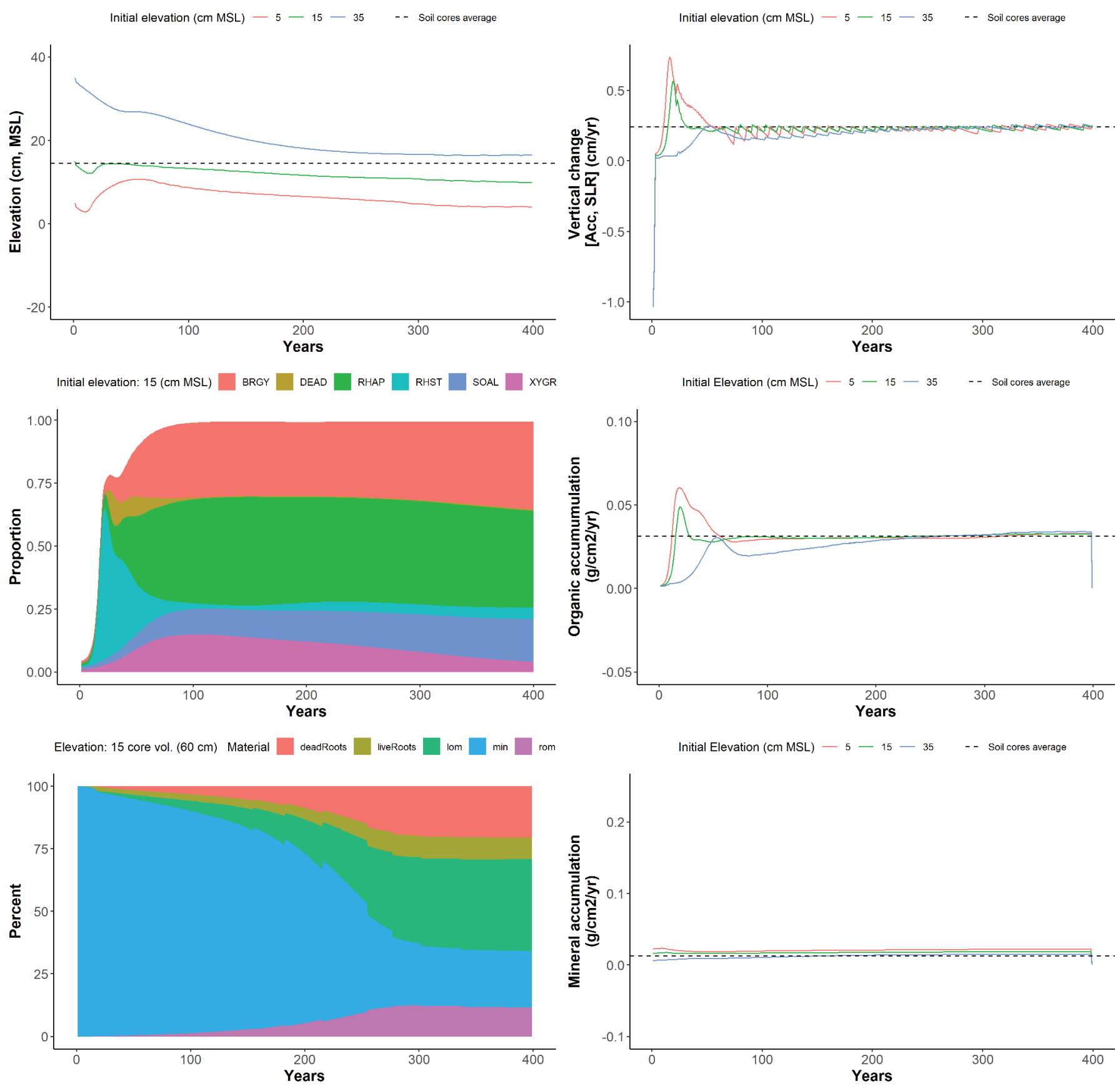

Figure 2.5. Calibration of elevation-related parameters using soil core-derived accretion and organic and mineral accumulation values at three initial model elevations, Enipoas, Pohnpei, Federated States of Micronesia, using a 400-year spin-up period. 

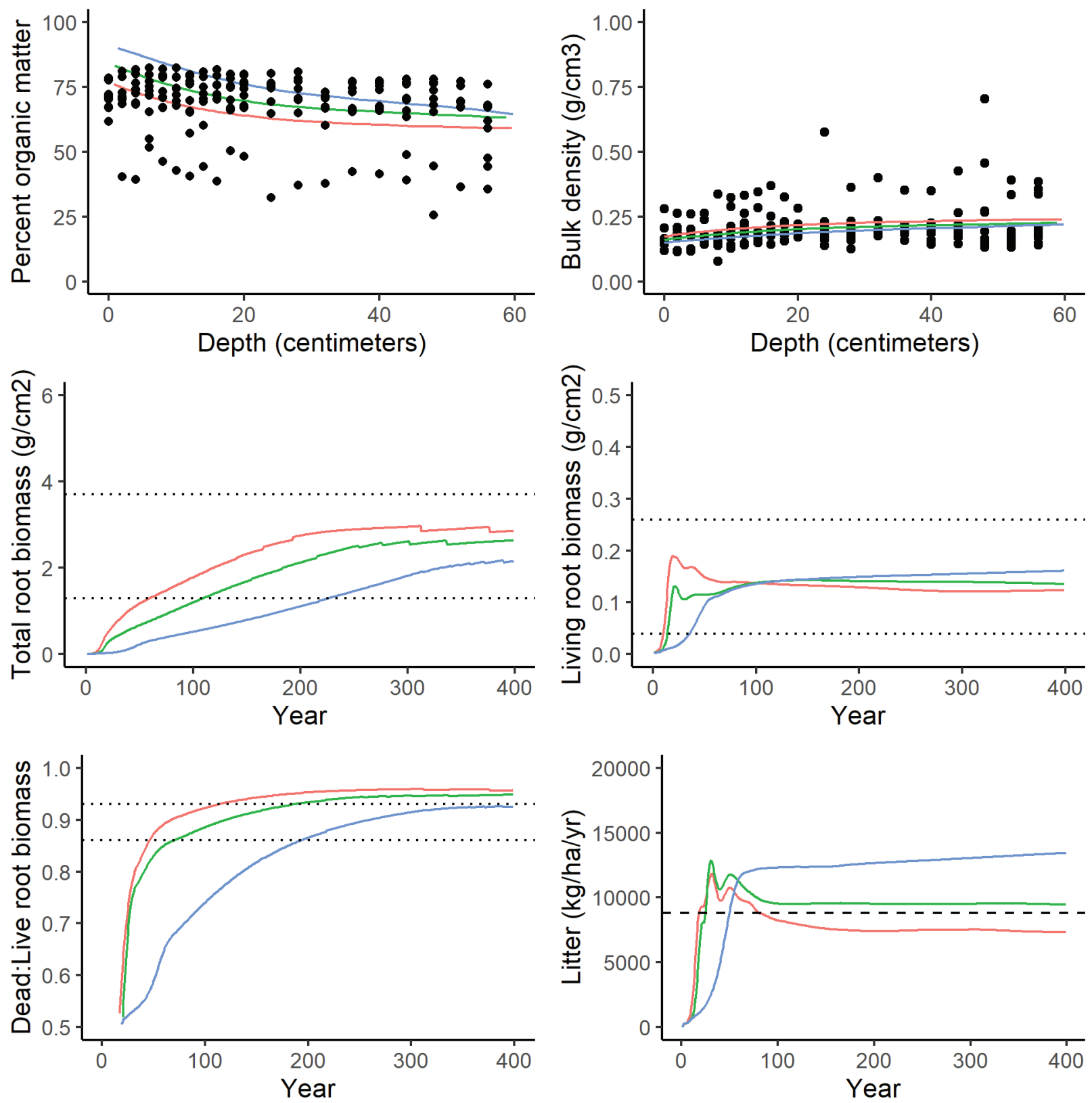

-... Published range - - Published mean

- Soil core data Elevation - $5-15-35$

Figure 2.6. Comparison of modeled soil and biomass characteristics with data from soil cores and the literature, Enipoas, Pohnpei, Federated States of Micronesia, using three initial model elevations (centimeters, mean sea level) and a 400-year spin-up period. 

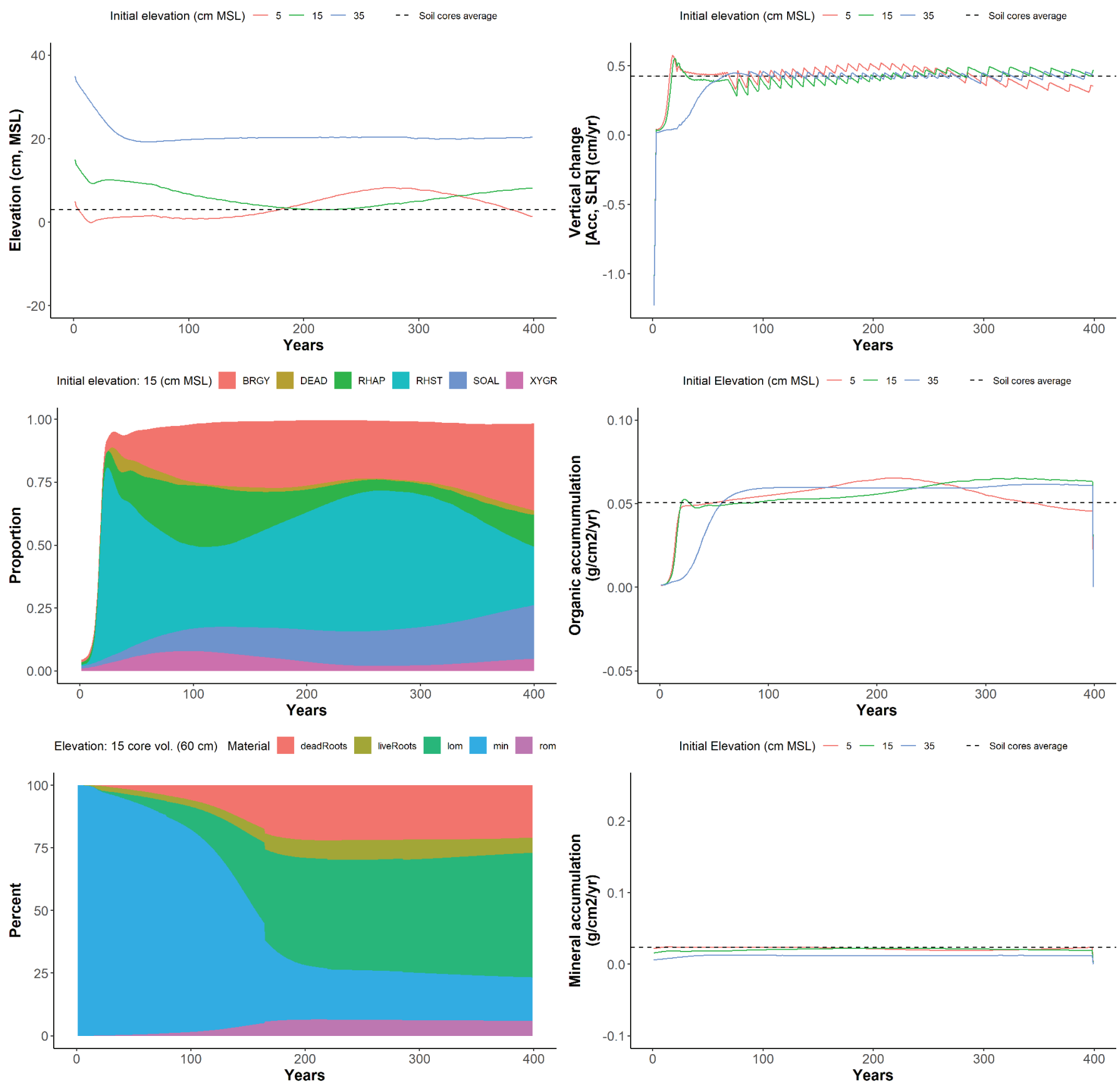

Figure 2.7. Calibration of elevation-related parameters using soil core-derived accretion and organic and mineral accumulation values at three initial model elevations, Palikir, Pohnpei, Federated States of Micronesia, using a 400-year spin-up period. 

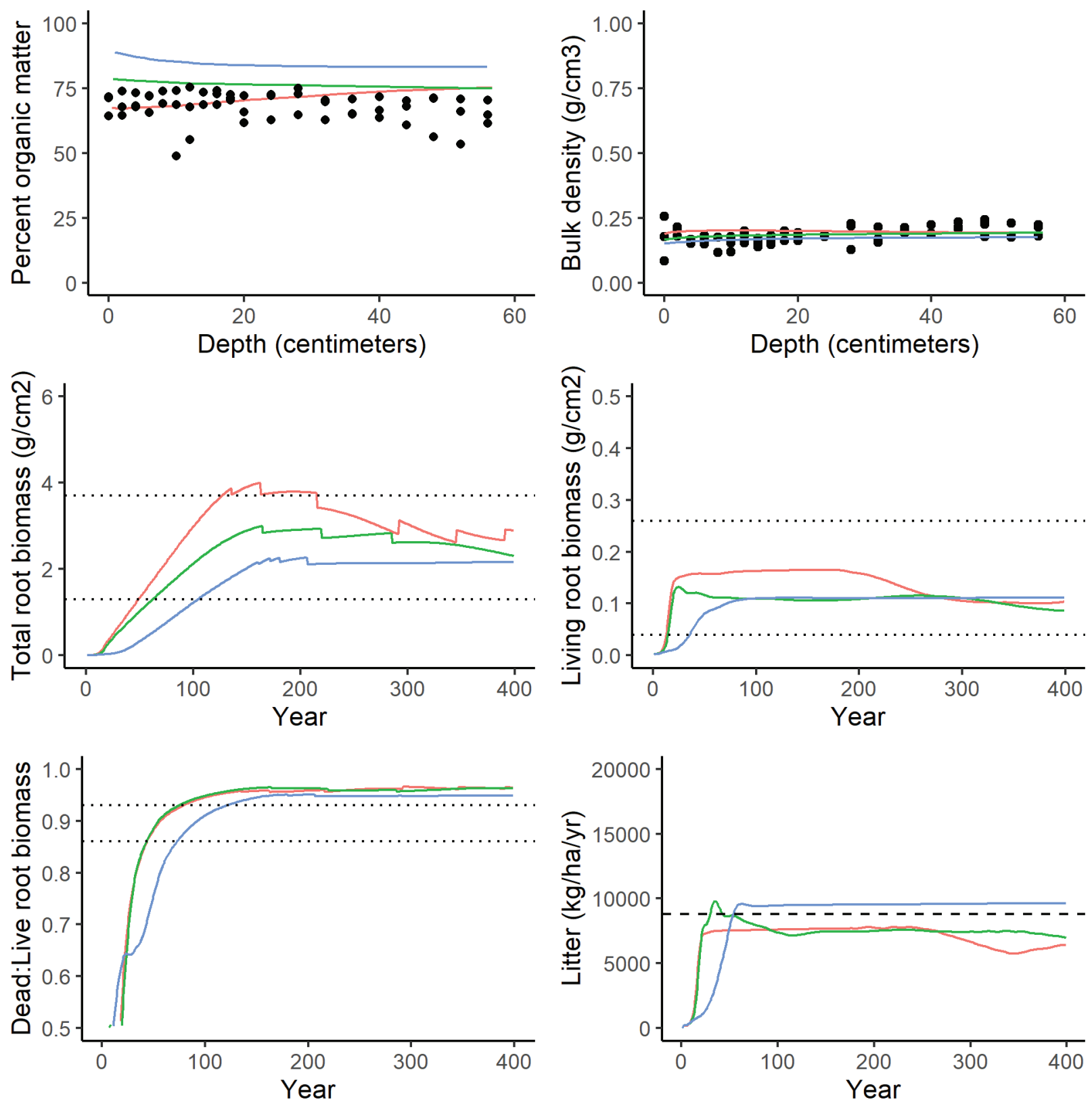

.... Published range - - Published mean

- Soil core data Elevation - $5-15-35$

Figure 2.8. Comparison of modeled soil and biomass characteristics with data from soil cores and the literature, Palikir, Pohnpei, Federated States of Micronesia, using three initial model elevations (centimeters, mean sea level) and a 400-year calibration period. 

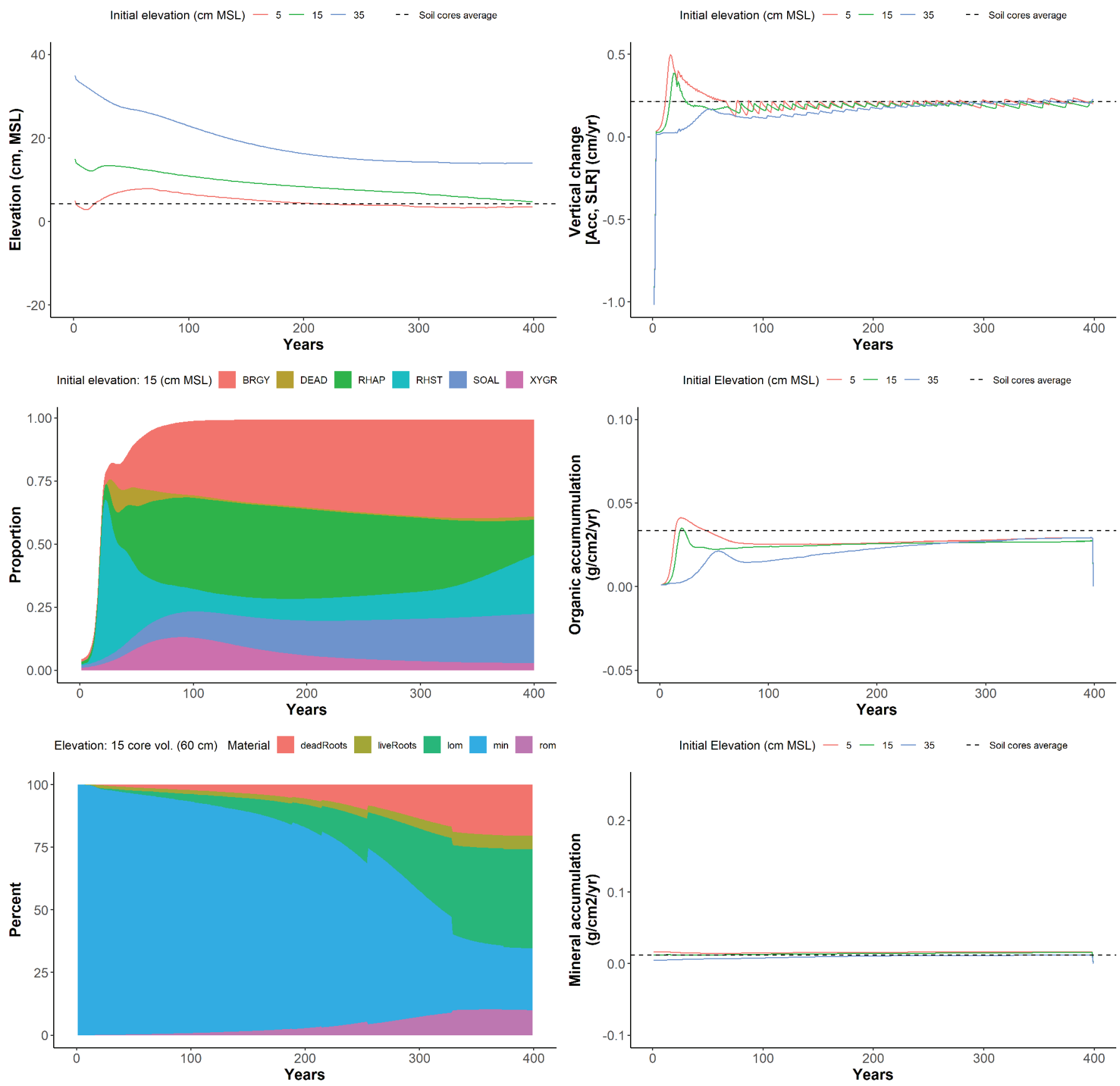

Figure 2.9. Calibration of elevation-related parameters using soil core-derived accretion and organic and mineral accumulation values at three initial model elevations, Pwudoi, Pohnpei, Federated States of Micronesia, using a 400-year spin-up period. 

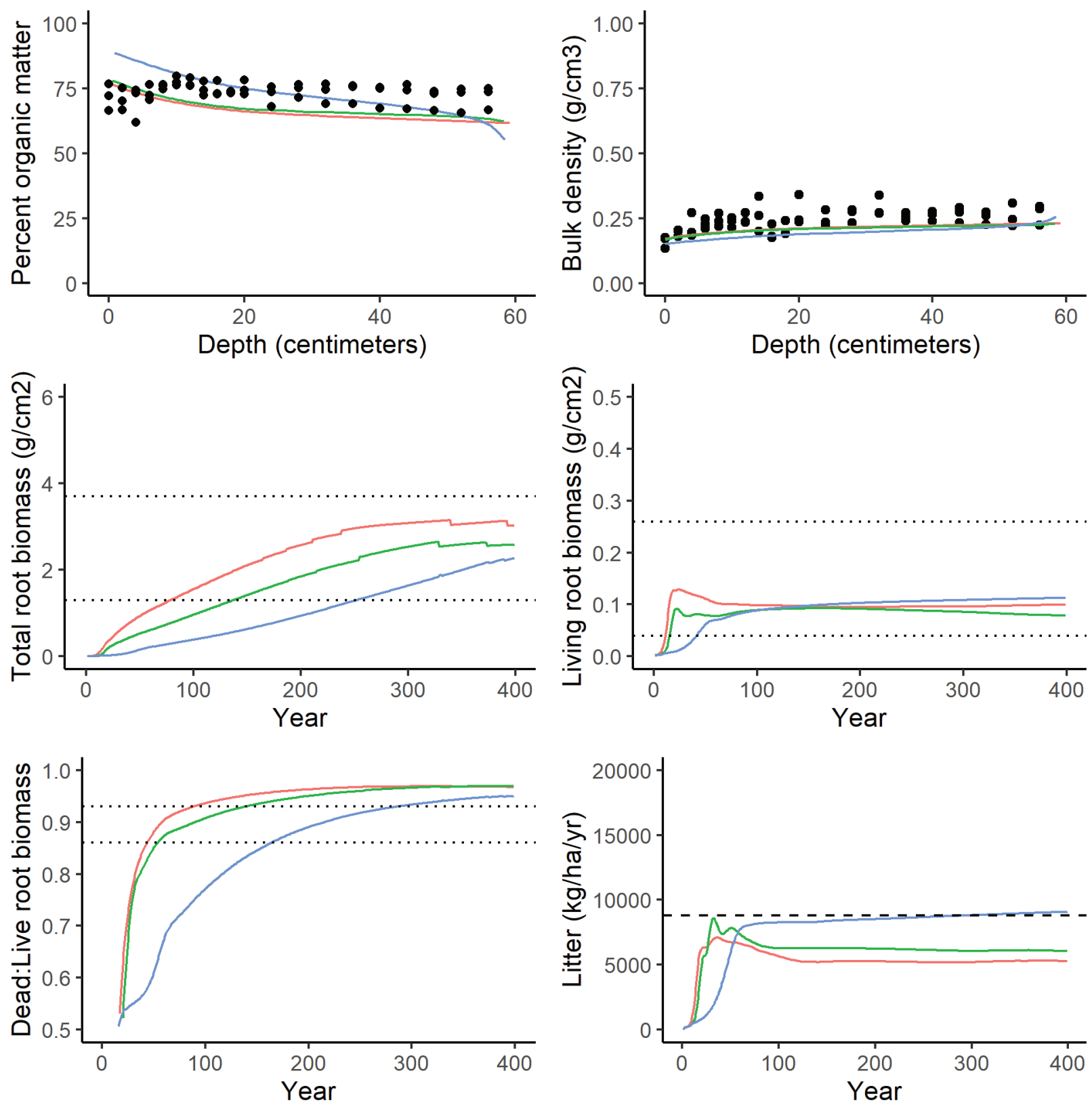

... Published range - - Published mean

- Soil core data Elevation - $5-15-35$

Figure 2.10. Comparison of modeled soil and biomass characteristics with data from soil cores and the literature, Pwudoi, Pohnpei, Federated States of Micronesia, using three initial model elevations (centimeters, mean sea level) and a 400-year calibration period. 

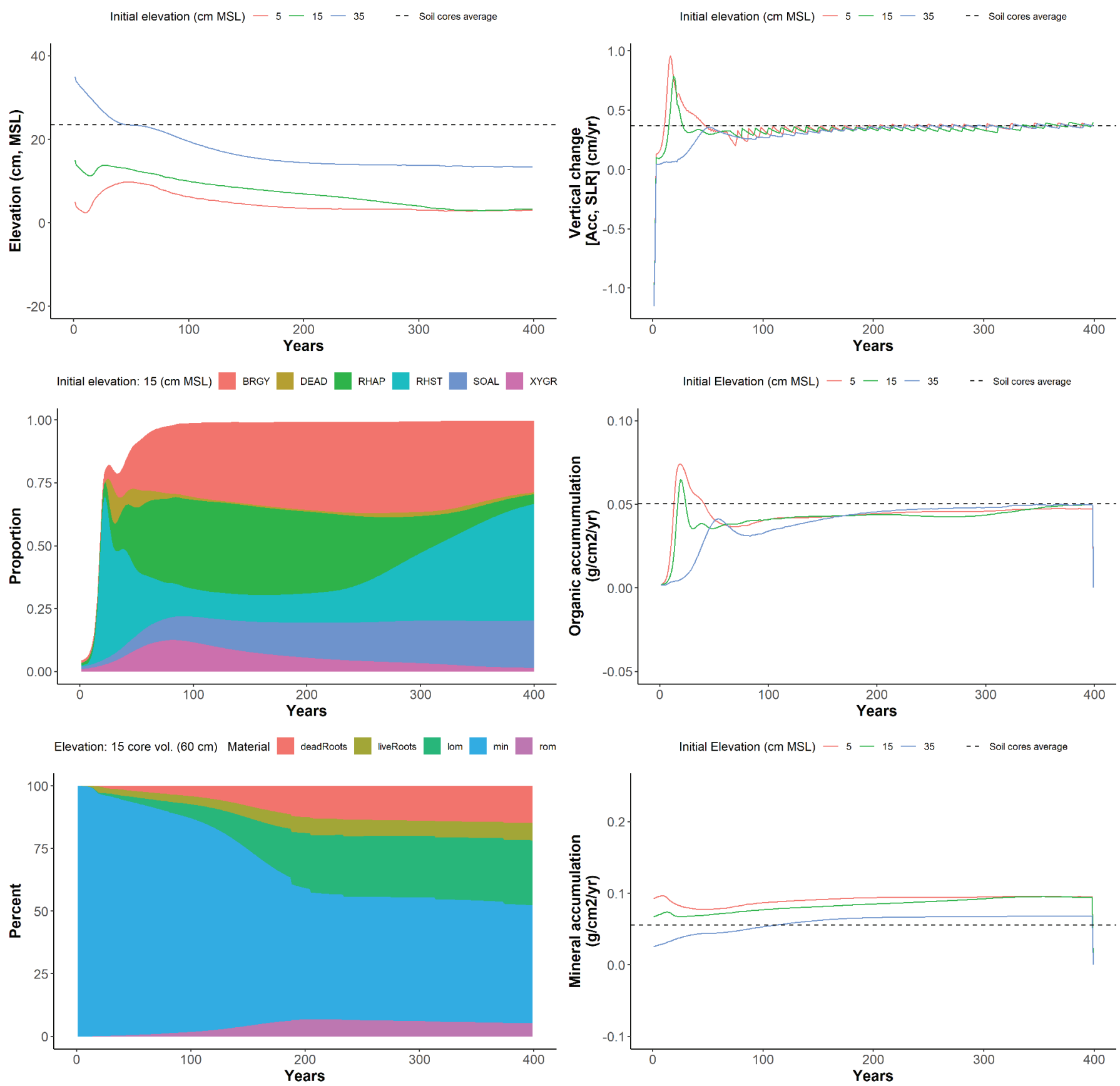

Figure 2.11. Calibration of elevation-related parameters using soil core-derived accretion and organic and mineral accumulation values at three initial model elevations, Sapwalap, Pohnpei, Federated States of Micronesia, using a 400-year spin-up period. 

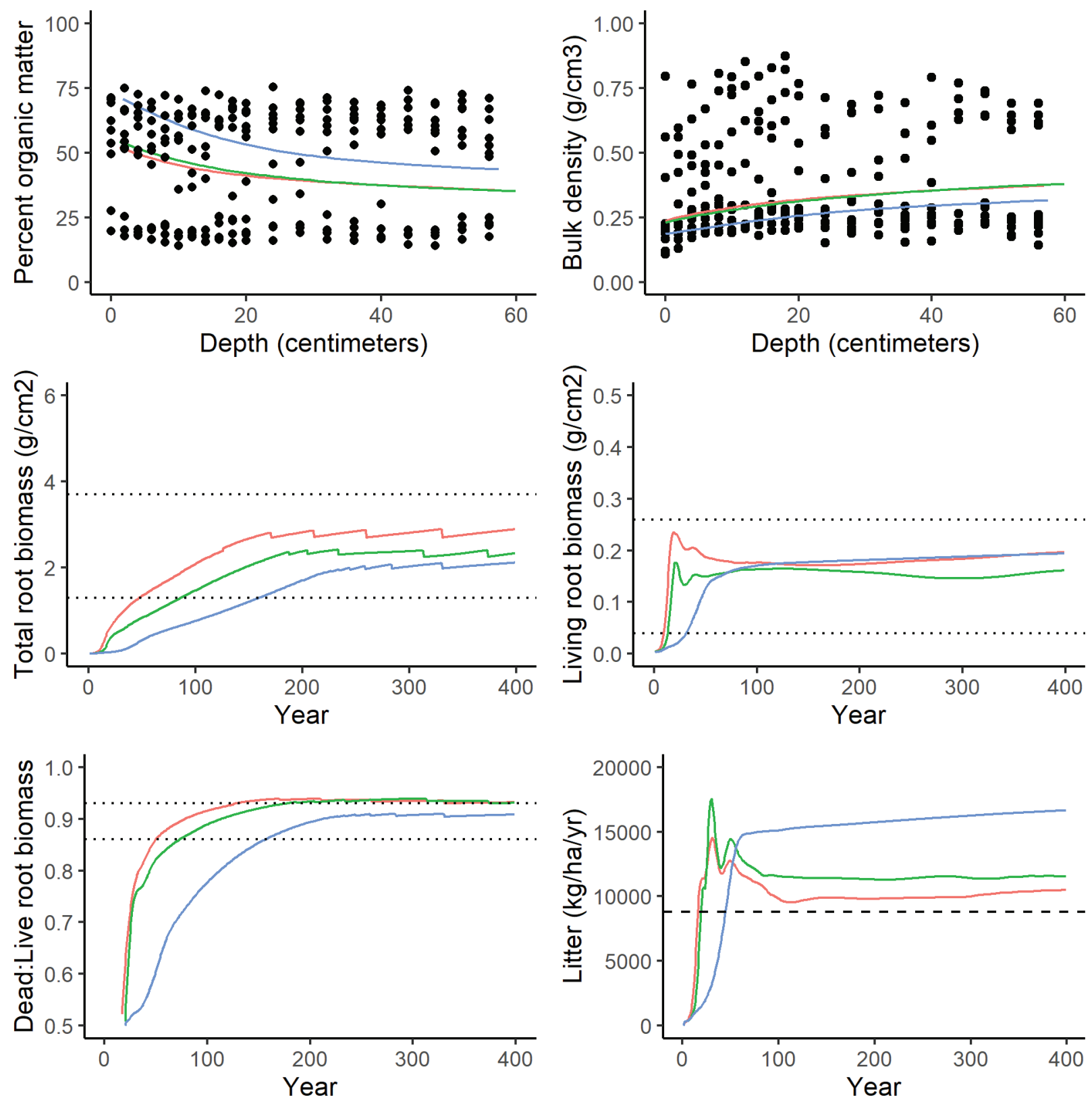

-... Published range - - Published mean

- Soil core data Elevation - $5-15-35$

Figure 2.12. Comparison of modeled soil and biomass characteristics with data from soil cores and the literature, Sapwalap, Pohnpei, Federated States of Micronesia, using three initial model elevations (centimeters, mean sea level) and a 400-year calibration period. 

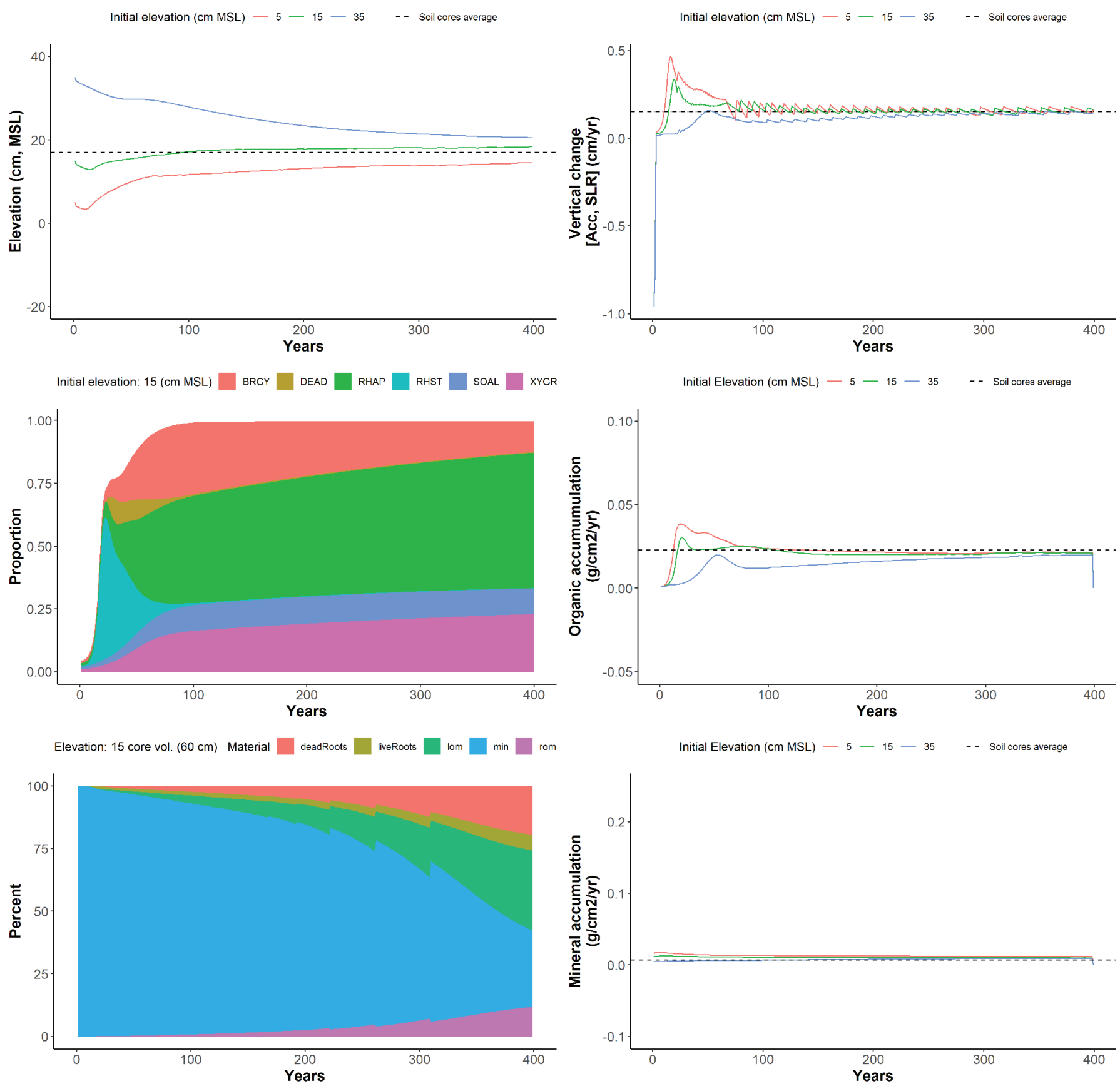

Figure 2.13. Calibration of elevation-related parameters using soil core-derived accretion and organic and mineral accumulation values at three initial model elevations, West, Pohnpei, Federated States of Micronesia, using a 400-year spin-up period. 

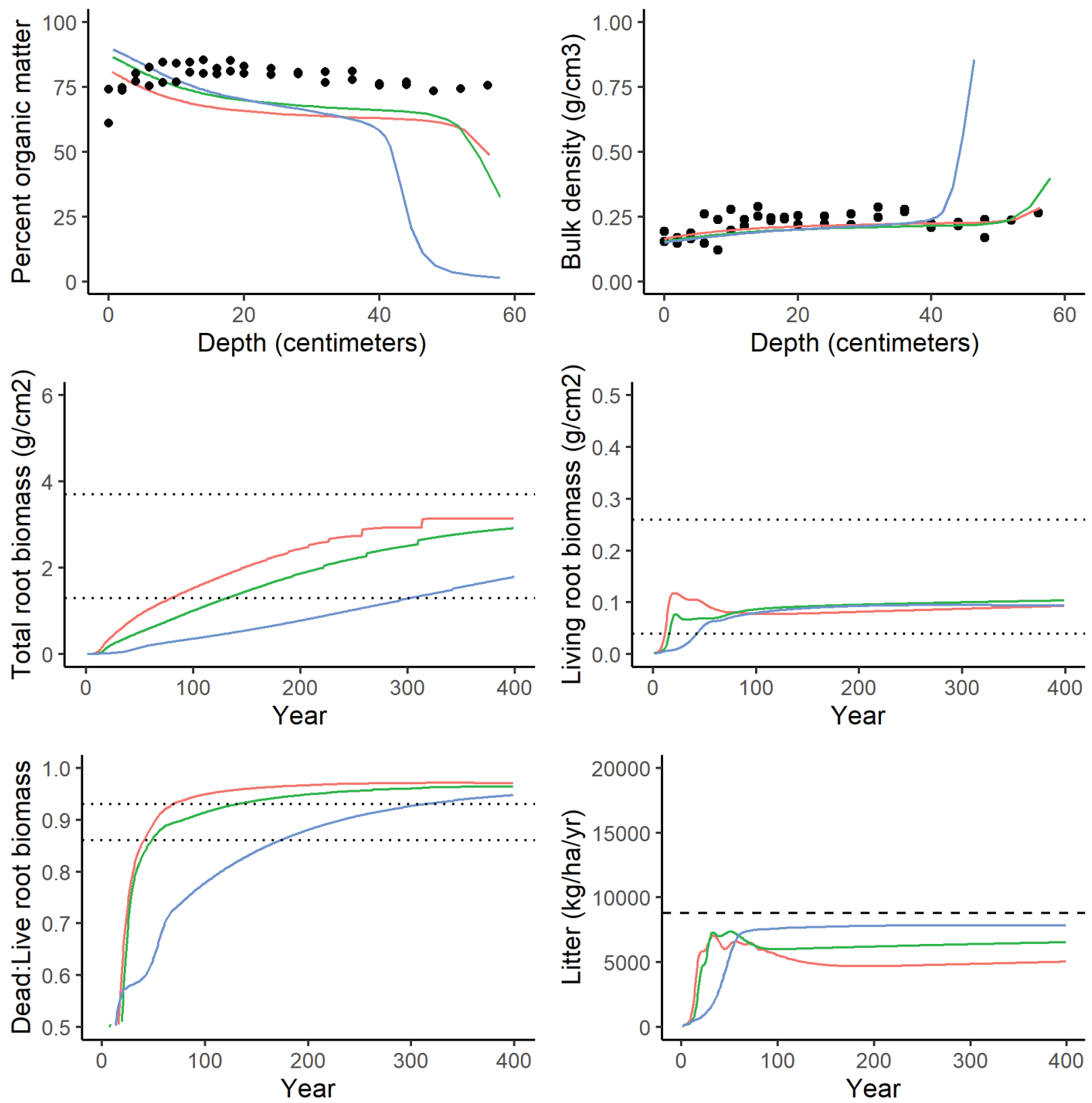

-... Published range - - Published mean

- Soil core data Elevation - $5-15-35$

Figure 2.14. Comparison of modeled soil and biomass characteristics with data from soil cores and the literature, West, Pohnpei, Federated States of Micronesia, using three initial model elevations (centimeters, mean sea level) and a 400-year calibration period. 
For more information concerning the research in this report, contact the

Director, Western Ecological Research Center

U.S. Geological Survey

3020 State University Drive East

Sacramento, California 95819

https://www.usgs.gov/centers/werc

Publishing support provided by the U.S. Geological Survey

Science Publishing Network, Sacramento Publishing Service Center 
